\title{
Can fiscal austerity be expansionary in present-day Europe? The lessons from Sweden*
}

\author{
Lennart Erixon** \\ Department of Economics, Stockholm University, Sweden
}

In the aftermath of a deep recession and public budget crisis, a Social Democrat government pursued an ambitious fiscal austerity policy in Sweden in the mid 1990s. Economic advisors were guided by the idea that fiscal austerity would have neutral or expansionary effects on output and employment. In order to avoid large public deficits in the future, the government also introduced radical fiscal rules. The main conclusion in this article is that the fiscal austerity measures in the mid 1990s delayed the Swedish economic recovery and that neither these measures nor the radical fiscal rules were responsible for Sweden's impressive macroeconomic performance in the following years. The positive economic development in Sweden up until the Great Recession was driven by export, profit and technology, reflecting an international upswing and the country's flexible exchange rates and industrial composition. The floating exchange rate, together with independent monetary policy and luck, explain why Sweden could avoid a sharp decline in GDP growth during the global financial and EMU crises. The demanding fiscal rules restricted the possibilities and willingness of the non-socialist government to respond to high unemployment with an expansionary fiscal policy.

Keywords: fiscal austerity, fiscal rules, Swedish stabilization policy, Swedish growth

JEL codes: $C 32, E 22, E 43, E 62$

\section{INTRODUCTION}

The Troika (the EU commission, the IMF and the ECB) and Germany have hitherto recommended that the EMU countries severely hit by a public debt crisis should reduce the debt and thus stimulate economic growth, both in the short and long term, by means of fiscal austerity. Advocates of the policy refer to sound economic theories and the prevalence of good examples. One influential argument for fiscal restraint is based on Sweden's past experiences. During the first half of the 1990s, Sweden suffered a deep recession and financial crisis, leading to mass unemployment

* This article has its origin in a speech at the Madariaga College of Europe Foundation, Brussels, 23 November 2012. A draft was presented at the EuroMemo Group Conference, London, 20-23 September 2013. I am grateful for the constructive comments by the participants, by Johan Lönnroth and Markus Marterbauer, and by two anonymous referees. I also thank Erika Viklund who has checked and improved my English.

** E-mail: lex@ne.su.se. 
and a large public budget deficit. In the middle of the decade, a Social Democrat government pursued a very restrictive fiscal policy. During the second half of the 1990 s, this government also introduced strict fiscal policy rules. The conventional view, both in Sweden and abroad, is that the tight fiscal policy in the mid 1990s and the domestic fiscal rules constituted a success story. The country soon attained a public budget balance. And from the mid 1990s until the global financial crisis in the late 2000s, Sweden displayed higher GDP growth than the EU and OECD countries on average, and also than the small open Western European countries on average. In the following years, Sweden managed to escape a financial and public budget crisis similar to that of the early 1990s. Among the OECD countries, in 2008-2013, only South Korea, Australia and Luxembourg had consistently lower general-government gross debts (as a share of nominal GDP) than Sweden (OECD Economic Outlook 2014, no 2, annex table 32, and Eurostat database). According to Eurostat, the Swedish debt ratio was 43.9 per cent in 2014. Moreover, between 2008 and 2013, Sweden had (together with Austria) higher GDP growth (0.7 per cent per year on average) than other EU countries (except for some new Eastern European members), and also than those Nordic countries (Iceland and Norway) that have remained outside the EU (OECD Economic Outlook 2014, no 2, annex table 1, and the Eurostat database).

The fiscal austerity measures in Sweden enjoyed overwhelming political support. Parties other than the Social Democrats (including the Left Party) were anxious to point out, for the Swedish record, that they had supported the restrictive fiscal policy of the mid 1990s. They emphasized, as did leading Swedish economists, that fiscal consolidation was inevitable and furthermore achieved by an ideal combination of expenditure cuts and tax increases (Swedish Economic Association 1995; 1997; Lönnroth 2004). What is more, all parties in Parliament endorsed, immediately or with some delay, the fiscal rules. (The Left Party did not reject the surplus target for the public sector until 2010.) The Social Democrat-Green Party coalition government, in office since September 2014, has recently initiated an evaluation of the need for a public budget surplus in the medium term, an essential component of the fiscal framework in Sweden. But the government still declares, like representatives for the former centre-right coalition government (2006-2014), that the fiscal rules have 'served us well' (Swedish Ministry of Finance 2014a, ch. 4; 2014b, pp. 10-13; Dagens Nyheter 2015).

This paper is primarily a case study aimed at detecting the importance of fiscal austerity for Sweden's macroeconomic performance since the mid 1990s. The conclusions are based on both a qualitative and a quantitative analysis of the real effects of the country's fiscal policy in the short and long run. The qualitative analysis includes a comparison between Sweden and other OECD countries, especially the other small open Western European countries: Norway, Finland, Denmark, Austria, Belgium, the Netherlands and Switzerland. The quantitative part of the article is mainly a time-series study of the determinants of investment in the Swedish business sector. But the conclusions in the article are buttressed by findings from earlier inquiries.

The conclusion drawn is that fiscal austerity in the mid 1990s actually delayed the Swedish recovery and that neither this policy nor the fiscal rules were major factors in Sweden's good growth performance up until the global financial crisis. The positive economic development was driven mainly by export, profit and technology reflecting an international recovery and favourable exchange-rate and industry-structural conditions. Moreover, the independent monetary policy and the depreciation of the krona (SEK) explain, together with luck, why Sweden was more leniently hit by the global financial and eurozone debt crisis. 
The article first depicts the background to the austerity policy and the introduction of fiscal rules in Sweden in the 1990s (Section 2), the scope of these fiscal measures and rules from an international perspective (Section 3), and the content of the underlying economic theories (Section 4). The following two sections (5 and 6) scrutinize the short- and long-run real effects, respectively, of Swedish fiscal restraint. A separate section (7) analyses the importance of fiscal policy and the fiscal rules for Sweden's relatively good growth performance after the collapse of Lehman Brothers. The final section (8) summarizes the analysis of the preceding sections and makes an overall evaluation of the macroeconomic and social consequences of the fiscal consolidation policy in Sweden since the mid 1990s.

\section{THE INTRODUCTION OF A NEW ECONOMIC POLICY REGIME}

In the 1980s, an international boom, two devaluations of the SEK and an abandonment of the restrictions on bank lending, in combination with a tax system favouring borrowing, resulted in serious overheating and (relatively) high inflation in Sweden. Fuelled by the development of new financial instruments and institutions, an economic bubble appeared, especially in stocks and commercial real estates. The early 1990s saw a collapse of the stock, housing and commercial real-estate markets in Sweden. In consequence, there was a bank crisis and an exceptional decline in private consumption and investment. The depression was largely domestic and no other OECD country, except Finland, experienced a comparable crisis at that time. Swedish GDP fell in absolute terms 3 years in a row. The decline in Swedish GDP growth and employment between 1991 and 1993 was actually larger than that during the Great Depression of the 1930s (Edvinsson 2005, tables 9.7 and 9.12). Unemployment shot up from 1.5 per cent in 1990 to above 9 per cent in 1993-1994. Speculative attacks against the SEK in the early 1990s also led to the collapse of the fixed exchange-rate system in November 1992. Furthermore, a 3.4 per cent budget surplus for general government as a share of nominal GDP in 1990 turned to an 11.3 per cent deficit in 1993, a figure at the time only comparable to Greece. And the Swedish gross public debt as a share of GDP increased from 47 per cent in 1990 to 84 per cent in 1994 (OECD Economic Outlook 2005; 2007b, no 2, annex tables 27 and 32).

The growing public budget deficit in Sweden during the first half of the 1990s was the result of a combination of built-in stabilizers and expansionary fiscal policies, inter alia, through extraordinary bank subsidies. ${ }^{1}$ A non-socialist coalition minority government in 1991-1994 had the ambition, but not the internal cohesion and time, to implement a radical programme for fiscal consolidation. The programme was mainly carried out by the Social Democratic minority government installed in October 1994. The restrictive fiscal policy of the mid 1990s, when the rate of unemployment was still high, was a clear break with the Swedish economic policy embraced in the early 1930s. At the initiative of leading Social Democrats and economists belonging to the so-called Stockholm School of Economics, Sweden was an early adopter of Keynesian ideas of active counter-cyclical economic policy.

1. The OECD measure of government cyclically adjusted balances gives a larger prominence to lax fiscal policies than to built-in stabilizers when the growing Swedish budget deficit 1991-1993 is to be explained (see OECD Economic Outlook 2007, no 2, annex tables 27 and 28). But the OECD estimates probably exaggerate the importance of discretionary fiscal measures for the Swedish public budget crisis in the early 1990s and probably also for the following public budget consolidation. 
The restrictive fiscal policy in Sweden in the mid 1990s was made possible for several reasons (see Erixon 2011). First, the trauma of the economic crisis at the beginning of the decade had an equal impact on people of all ages and genders, and in all sectors. This allowed a consensus to emerge on the damaging effects of inflation and the policy response was accepted even by the central trade-union organizations. Second, new economic thinking was emerging, stating that unemployment rates of 1.5 per cent were unsustainable and that a reduction in unemployment could only be made through product market deregulation and measures promoting flexibility in the labour market. Third, in the 1980s and 1990s, economic experts governed by new economic thinking extended their influence over Swedish economic policy and the blue-collar trade-union confederation, LO, had a correspondingly decreasing impact. Fourth, EU integration played a role in making fiscal austerity possible due to the Maastricht convergence rules prohibiting a large public budget deficit and debt (see the 3 per cent GDP deficit rule and the 60 per cent GDP debt rule). The Social Democrat government presented a national convergence programme in June 1995. The government referred to the programme in 1997, when arguing for further budget improvements to prevent a public budget deficit larger than 3 per cent (Swedish Ministry of Finance 1995b; 1996, pp. 14-15 and appendix 2, pp. 1-2; 1997, p. 18). Sweden had entered the EU in 1995 after a close referendum the year before (52.3 per cent of the voters supported membership).

The four above-mentioned factors were also decisive for the introduction of fiscal and monetary targets and other changes in the economic-policy regime in Sweden in the 1990s and 2000s. The switch to flexible exchange rates was followed by a decision by the Central Bank (the Riksbank) to adopt an inflation target of 2 per cent (with a permitted departure of 1 percentage point in both directions until 2011) used as a guideline for monetary policy from 1995. The growing independence of the Riksbank with price stability as the ultimate goal was finally settled in 1998. By adopting a flexible inflation target the independent Riksbank also gave priority to output stabilization (Svensson 2010, pp. 60-62). But the Riksbank did not abandon the central idea in the 'new macroeconomic consensus' (the new neoclassical synthesis) that monetary policy cannot affect the output level in the medium and long term (see the quantitative theory of money).

Furthermore, Social Democrat governments made some fiscal reforms during the second half of the 1990s to prevent the re-emergence of large public deficits. The use of a top-down budget process for central government from 1996 restricted the possibilities for Parliament to increase expenditure by a breakdown of the budget items. Moreover, a Social Democrat government proposed a ceiling on central government expenditure for 3 years to come, a rule enforced from 1997. The same year the Social Democrats introduced a fiscal target for general government (implemented incrementally during 1997-2000), demanding a surplus of 2 per cent of GDP for each business cycle. The reduction in target from 2 to 1 per cent in 2006 did not reflect an easing of fiscal rules. Rather, it was a consequence of EU regulation requiring that some parts of the pension system should be included in the private sector. Finally, the Social Democrats decided in 1997 to restrict the extent to which local and county governments could pass budgets with a deficit. The new law, introduced in 2000, stated that these governments must eliminate budget deficits within 2 years.

\section{SWEDISH FISCAL RESTRAINT IN A COMPARATIVE PERSPECTIVE}

The substantial Swedish public budget deficit in 1993 vanished rapidly in the following years, to be completely eliminated by 1998. And from 1995 to 2000 , the gross 
public debt as a ratio of nominal GDP decreased by 17 percentage points and the net public debt in relation to GDP by 20 percentage points. In 2001, Sweden's net public debt even became negative (OECD Economic Outlook 2012, no. 2, annex tables 32 and 33). Swedish fiscal policy in the mid 1990s was, from a historical perspective, very restrictive (see Matthiessen 1971; Braconier and Holden 1999). Built-in stabilizers made a substantial contribution to the reduction and eventual disappearance of the public budget deficit in Sweden. But according to OECD estimates, fiscal austerity was the major factor in the public budget consolidation of 1994-1998. Besides, the austerity programme in 1995-1998 was front-loaded, thus the Social Democrats had no intention of postponing the deflationary measures until the end of their 1994-1998 term of office (Henriksson 2012, pp. 2 and 6). ${ }^{2}$

Swedish fiscal restraint in the mid 1990s was also exceptional from an international perspective. The OECD secretariat regularly presents data on the cyclically adjusted public budget balance in member countries. Table 1 shows the OECD countries and periods with the strongest fiscal restraint from 1970 (the first year of the OECD time series) up until the current global financial crisis. From the perspective of stabilization policy it is less meaningful to define periods longer than 5 years. The table also excludes periods shorter than 3 years.

Disregarding the fiscal policy in Germany in 1996-1998 and the Netherlands in 1996-1999, Swedish fiscal policy in 1995-1998 is the most obvious example of fiscal austerity in the OECD area in the 3-and 4-year perspective. The Social Democrat

Table 1 Countries and periods with the strongest fiscal restraint in the OECD area, 1970-2007 (general government). Percentage point changes in the cyclically adjusted general balance (as a percentage of potential GDP), annual data

\begin{tabular}{lccc}
\hline & 3 years & 4 years & 5 years \\
\hline Belgium 1993-1997 & 4.6 & 5.8 & 6.5 \\
Canada 1994-1998 & 4.8 & 7.5 & 5.9 \\
Finland 1996-2000 & 6.8 & 7.4 & 9.8 \\
Germany 1996-2000 & 7.4 & 7.7 & 9.8 \\
Greece 1994-1998 & 5.0 & 5.5 & 7.5 \\
Iceland 2002-2005 & 6.6 & 6.7 & - \\
Ireland 1985-1989 & 6.0 & 7.5 & - \\
Italy 1995-1999 & 4.7 & 5.1 & 6.1 \\
Japan 1999-2001 & 5.2 & - & - \\
Netherlands 1996-2000 & 7.1 & 8.0 & 8.6 \\
New Zealand 1989-1994 & 3.1 & 5.1 & 5.5 \\
Norway 1994-1997 & 4.1 & 5.4 & - \\
Sweden 1994-1998 & $\mathbf{7 . 3}$ & $\mathbf{7 . 8}$ & $\mathbf{8 . 7}$ \\
United Kingdom 1979-1982 & 6.5 & 7.1 & - \\
United Kingdom 1995-1999 & 5.3 & 5.9 & 6.9 \\
\hline
\end{tabular}

Source: Muller and Price (1984, table 1); OECD Economic Outlook 2000; 2002, no 1, annex table 31; 2005, no $1 ; 2010$, no 2; 2012, no 2, annex table 28 .

2. In 1993, an economic commission appointed by the centre-right government and headed by Assar Lindbeck had warned of a frontloading consolidation strategy, fearing a deepening of the economic crisis. The commission recommended that necessary cuts in public transfers should be postponed until the end of the fiscal consolidation period 1994-1998 (SOU 1993:16, pp. 188-189; see also Erixon and Skult 1996). 
fiscal policy in Sweden in the mid 1990s seems to have been more restrictive than the Thatcher policy in the United Kingdom in the period 1979-1982. And countries with a similar or stronger fiscal restraint than Sweden pursued this policy in a steady recovery with falling unemployment rates (in the late 1990s). Many difficulties are involved in the measuring and comparison of discrete fiscal policy (see Barnes et al. 2012, p. 16). But new methodologies and estimates by the OECD secretariat in the mid 2000s did not alter the earlier estimates of the cyclically adjusted budget balances since 1980 in any significant way (Girouard and André 2005). We can, rather confidently, draw the conclusion that the public budget consolidation policy in Sweden in the 1990s was, from an international perspective, radical. The question is whether the Swedish fiscal rules were outstanding as well.

The multi-dimensional character of the fiscal rules, but also the variation in obedience, makes it difficult to compare the actual strictness of fiscal rules in different OECD countries. ${ }^{3}$ In some respects, the Swedish fiscal rules are less demanding than those of other OECD countries. For example, they are not sanction-based, like the rules in the US, Canada (for the provinces) and the Stability and Growth Pact (SGP) between the EMU countries, particularly after the 'six pack' EU regulation in December 2011 and the 'Fiscal Compact' signed by the European Council in March 2012. As an EU member, Sweden must formally adhere to the SGP. However, as a non-EMU country, Sweden is not constrained by the sanctions in the SGP. Moreover, Sweden only signed the treaty of summit participation in the Fiscal Compact, thus the country is not obliged to implement its sanctions and rules. Further, the Swedish restrictions on the public budget are not defined in the short run, or in terms of the public debt as in the SGP. Besides, to satisfy the SGP public-deficit target ( 3 per cent of GDP), the EU fiscal rules were sharpened by the Fiscal Compact, inter alia, excluding larger annual structural budget deficits than 0.5 per cent of nominal GDP (a 1 per cent deficit is permitted if the public debt is significantly below 60 per cent).

But an overall evaluation of the fiscal rules suggests that the Swedish fiscal rules are relatively strict. The public budget target for general government is explicitly numerical in Sweden, which is not the case in Denmark, Australia, Austria (until 2011), New Zealand and Canada (for the federal government and some provinces). The original SGP medium-term objective (1997) of a public budget close to balance or in surplus hardly satisfied the definition of a numerical target. Furthermore, the budget claims in the medium term are binding in the Swedish fiscal system (by a budget law since 2011), thus not only recommendations as in the SGP before the 'six pack' legislation and the Fiscal Compact. The Swedish claim on a public budget surplus in the medium term is also stronger than the corresponding claim in most OECD and EU countries and in the SGP even after the Fiscal Compact on at least a budget balance. ${ }^{4}$ And Sweden has a national fiscal target for both the budget balance and public expenditure, in contrast to, for example, Norway, the Netherlands, Australia, New Zealand, the USA and Canada (since the mid 1990s). By including, for example, the social

3. International compilations of the fiscal rules can be found in OECD (2002, pp. 132-134); Debrun et al. (2008); Barnes et al. (2012); Budina et al. (2012); CESifo (2012); Schaechter et al. (2012).

4. The stipulation of country-specific objectives for the budget balance in the medium term through the 2005 reform of the SGP, providing room for larger flexibility, also applied to Sweden. The 2005 (MTO) reform permitted public budget deficits (1 per cent of GDP) in the medium term (Franchino 2014, pp. 12-14). But Swedish fiscal policy was still restricted in the medium term by its more demanding domestic target. 
insurance system, the Swedish expenditure target for central government covers virtually all expenditure, while the Finnish expenditure target, inter alia, excludes payment from this system. (Similar exclusions of 'cyclically sensitive' public expenditure are also made in Denmark and Switzerland.) Moreover, in contrast to Germany, the UK (until 2008) and Italy (following the so-called Golden Rule), the Swedish target for the public budget balance does not exclude borrowing to invest. The restriction on the budget balance is fixed in Sweden, not flexible or conditional as in Norway (by the linkage to the government oil fund) and in Switzerland, Germany, Greece, Ireland, Italy, Portugal and Spain, mostly by reference to exceptional circumstances. Also the SGP makes exceptions for severe economic downturns.

The ambition of this article is not to calculate a general fiscal-rule index enabling a definition of the Swedish degree of rigor (cf. Kopits and Symanski 1998). Sweden would probably occupy a prominent place if the OECD countries were ranked on the basis of the overall strictness of domestic fiscal rules. The EU commission has constructed a numerical fiscal-rule index for the member countries. This EU index is based on the scope (coverage) but also the efficiency (strength) of the national rules in terms of statutory basis, enforcement and transparency. In 2000-2012 Sweden was, despite a low ranking of rule efficiency (European Commission 2006, p. 164), permanently among the top three EU countries with the strictest fiscal rules (European Commission 2014). Sweden fell from first to third place from 2010 to 2012 because of some new rules on structural public deficits in Spain (although not in force until 2020) and on public debt in Slovakia (International Monetary Fund 2012, p. 68). The fiscal rules were adopted earlier in Sweden than in the bulk of OECD countries.

During the 1998-2007 period, Sweden's budget balance was predominantly positive with a public deficit only during the recession in the early 2000 s in line with the medium-term budget target. It seems that the group of EU countries with the strictest rules has achieved the highest degree of fiscal discipline (European Commission 2006, pp. 159-161; 2010, graph II.4.3). For example, Greece, Portugal and Ireland had no expenditure target before the Fiscal Compact and no national fiscal rules at all before 2012. Moreover, in 1998-2007, the general government underlying balance as a percentage of potential GDP was, on average, 'better' in Sweden than in most other EU and OECD countries (OECD 2014, no 1, annex table 30). The strictness and early application of the fiscal rules in Sweden are major explanations for why the SGP (1997), institutionalizing the fiscal guidelines of the Maastricht Treaty (1992), played a minor role in Swedish fiscal policy-making even before the rejection of EMU membership in the 2003 referendum (see Swedish Ministry of Finance 1999). Most empirical studies verify, even when considering other determinants, that fiscal rules have been successful in reducing public deficits and debts (Alesina and Perotti 1999; European Commission 2006, pp. 159-167; Debrun et al. 2008; Badinger 2009, pp. 839-843; Dahan and Strawczynski 2010, pp. 9-10; Auerbach 2012, pp. 2-5; Combes et al. 2014, pp. 16-20).

However, it is necessary to nuance the view that the radical fiscal rules were responsible for the fast public budget consolidation and sharp reduction of the public debt in Sweden (cf. European Commission 2010, pp. 112-114; Franco and Zotteri 2010; Miyazaki 2011). Among the EU countries, Denmark, Finland and Belgium had a larger public saving surplus (on average) than Sweden in 1998-2007. In the same period, the budget surplus was also larger in Canada, Korea and New Zealand than in Sweden. And it was almost as large (on average) in Australia, Iceland and Italy as it was in Sweden. In fact, the OECD countries with a fiscal stance better than or almost 
as strong as Sweden's have relatively weak domestic (numerical) fiscal rules in general (Belgium and Finland) or no national rules for the budget balance in the medium term (Australia, Canada, Iceland, Italy and New Zealand). ${ }^{5}$ Besides, in 1998-2007, automatic stabilizers accounted for the major share of the improvement of the (general) government financial balance in Sweden ( 73 per cent according to estimates based on OECD Economic Outlook 2014, no 1, annex table 27 and 28). ${ }^{6}$

Moreover, the improvement in the budget balance seems not to have been the most important explanation for the substantial decline in Swedish public debt since the mid 1990s. Primary surpluses (determined by fiscal policies but also by built-in stabilizers) explained only 36 per cent (30 per cent) of the decline in net public debt in 1997-2007 (1997-2011). The re-evaluation of debts and assets was by far the most important factor behind the decline in Swedish public debt (Flodén 2012). The contribution of the primary surpluses to the reduction in net public debt was actually larger in Denmark, Belgium, Canada and Italy.

And the exogeneity of the fiscal rules (and new budget processes) in the 1990s can, in the Swedish (and Finnish) case, be called into question. These reforms, and also the fiscal consolidation policy from the mid 1990s, were largely induced by the deep economic crisis (and the related escalation of the public deficit and debt) at the beginning of the decade (see the impact of a stronger preference for fiscal discipline). A reasonable idea, however, is that the fiscal rules prolonged the collective memory of the preceding public budget crisis in Sweden (see Flodén 2012, p. 20).

To summarize, the fiscal austerity policy pursued in Sweden in the mid 1990s, and the fiscal rules introduced in the country during the same decade, were far-reaching in an international perspective. The fiscal austerity measures taken by the Social Democrat government contributed significantly to the rapid public budget consolidation in the mid 1990s. But the conclusion in the empirical literature that the large reduction of public deficits and debts in Sweden since the mid 1990s can be attributed to the country's new fiscal policy arrangements (including the new budgetary procedures) must be qualified. For example, the reduction in the (net) public debt did not primarily reflect improvements in the fiscal stance. And the improvement in the government budget balance in 1998-2007 primarily reflected the working of built-in-stabilizers. Moreover, the tight fiscal policy in the mid 1990s and the radical fiscal rules are primarily explained by the deep economic and financial crisis in the early 1990s. They were also explained (in interaction with the crisis) by the breakthrough of new theories on economic policy shared by leading politicians and economists in almost all OECD countries.

Thus, fiscal policy was basically tied up, in Sweden as in other OECD countries, by the priority in the new macroeconomic consensus given to low inflation, monetary policy in stabilization policy and to rules and institutions aimed at preventing timeinconsistent, partisan and election-oriented political decisions. The rational expectations theory underlying the new consensus on economic policy was a guiding star also for economic experts with a strong influence over Swedish fiscal policy in the 1990s and 2000s.

5. In Italy, a law demanding a balanced budget in the medium term for general government was not enforced until 2012 and did not go into effect until 2014.

6. In fact, the annual change in the general government underlying primary balance (excluding interest payment) in relation to potential GDP was on average slightly positive in 1998-2007 (estimates on the basis of OECD Economic Outlook 2014, no 1, annex table 30). 


\section{THE THEORIES OF EXPANSION THROUGH FISCAL RESTRAINT}

This section sheds light on the arguments by advisors to the Social Democratic Minister of Finance in the 1990s that the very restrictive fiscal policy in the middle of the decade and the radical fiscal rules would have neutral or even expansionary effects on Swedish GDP and employment. The advisors formulated these arguments at the time of the introduction of the fiscal consolidation policy and the fiscal rules or ex post. This section will also present the underlying macroeconomic theories. With some exceptions, the literature survey is restricted to theories that were available in the 1990s or used later by the advisors to the Minister of Finance at that time.

Economic experts to the Minister of Finance in the mid 1990s referred ex post to the possibility that the negative output effects of fiscal restraint could be offset by a lower propensity for household saving (Swedish Ministry of Finance 2000a, pp. 23 and 41). The Ricardian equivalence presupposes that the negative impact of fiscal restraint on output and employment will be fully neutralized by a decline in the private saving propensity (through expectations of tax cuts or higher public expenditures in the future). The economic advisors at the Ministry of Finance even claimed that a creditable fiscalausterity policy might have expansionary effects in the short run (ibid.). They could have referred to Giavazzi and Pagano (1990), who maintained, primarily by reference to the economic policy in Denmark in the mid 1980s, that tax increases may enhance aggregate demand by the positive wealth effect on private consumption. Household wealth is stimulated by the fall in expected inflation (increasing the real value of future interest payments to households) and by the reduction in long-term (real) interest rates (having a positive effect also on private investment). Furthermore, cuts in public expenditure today result in household and firm expectations that taxes will be reduced in the future. The macroeconomic model based on rational expectations in Blanchard (1991) stresses that restrictive fiscal policy might have expansionary effects on private consumption and investment in the short run because of a reduction in expected interest rates. In this model, the decline in long-term interest rates reflects that rational agents are anticipating that fiscal-austerity policy will reduce the (real) interest rates in the future. This theory became a crucial component of the new consensus in macroeconomics in the 1990s and 2000s.

High civil servants within the Swedish Ministry of Finance primarily emphasized in the middle of the 1990s that fiscal restraint would be expansionary by inducing a fall in the long-term interest rates (Swedish Ministry of Finance 1995b; 2000a, pp. 23-24; Swedish Government 1996, ch. 1). Specifically, they blamed the increase in public deficit in Sweden in the early 1990s for having caused the growing interest-rate gap between Sweden and Germany in 1994-1995 (Swedish Ministry of Finance 1994, appendix 1.1, p. 95; 1995a, appendix 1, p. 3; 2000a, p. 41). The experts leaned on the (uncovered) interest parity condition although without any explicit reference. They assumed that the restrictive fiscal policy would reduce expected inflation and therefore the expectations of a depreciation of the SEK leading to a decline in long-term interest rates (Swedish Ministry of Finance 1994, appendix 1, p. 38; 1995a, appendix 1, p. 4).

The theories above about the expansionary effect of fiscal restraint, and the pertinent arguments in the mid 1990s by the economic advisors to the Swedish government, did not rest on any assumption about an expected or actual easing of (domestic) monetary policy. Later, an advisor to the Swedish Minister of Finance at that time suggested, primarily by reference to Dixit and Lambertini $(2000 ; 2003)$, that fiscal contraction in the mid 1990s stimulated the Swedish economy by eliciting an easier monetary policy. This argument for a relation between fiscal and monetary 
policy was an ex post rationale for the front-loading feature of the restrictive fiscal policy: in order to create creditability, extensive austerity programmes were already launched at the beginning of the consolidation period (Henriksson 2012). According to the underlying economic theory, a commitment to fiscal restraint is a signal to the independent Central Bank that it can conduct a more expansionary monetary policy. Lower interest rates will, inter alia, weaken the currency and thus have a positive effect on net exports. Paradoxically, this argument for fiscal restraint conflicted with the hopes of the Swedish Ministry of Finance at the beginning of the budget consolidation period (see the interest parity condition) that the SEK would be strengthened by the restraining fiscal policy (see Swedish Ministry of Finance 1994, appendix 1, p. 49; 1995a, p. 25; Henriksson 2012, p. 2).

The Ministry of Finance mentioned, but downplayed, the risk that the fiscal restraint measures in the mid 1990s would hamper GDP and employment (Swedish Ministry of Finance 1994, appendix 1, p. 33). It also toned down the possibility that an initial decrease in GDP and profits, and an increase in unemployment, would weaken confidence among households and firms, leading to secular stagnation, a possibility that had been highlighted by prominent representatives of the Stockholm School of Economics. Furthermore, when arguing in the mid 1990s that fiscal austerity would stimulate private consumption and investment, economic advisors to the Swedish Minister of Finance focused on the nominal interest rate. But a reduction in nominal interest rates in the aftermath of a restrictive fiscal policy is not necessarily connected with a reduction in real rates. In models forming the new macroeconomic consensus, fiscal restraint has ambiguous effects not only on aggregate demand but also on real interest rates per se (Blanchard 1991, pp. 375-377). There was an inconsistency between the arguments by the defenders of Swedish fiscal austerity in the mid 1990s that the policy would make a large contribution to the reduction of inflation expectations and simultaneously be expansionary. The more efficient the fiscal austerity policy is in reducing expected inflation, the higher the risk that this policy would increase the real interest rates.

The expert recommendations of the Swedish fiscal-austerity policy in the mid 1990s were not based on a clear distinction between the short- and long-run effects on GDP and employment. In established macroeconomic models, restrictive fiscal policy, in contrast to monetary restraint, has negative effects on the (real) interest rate in the medium term. The related stimuli of private investment would cause output to surge in the long run. Knowledge about this mechanism among rational agents is actually conditional upon the expansionary effects of fiscal restraint in the short run (see above). After the termination of the budget consolidation policy in the mid 1990s, the Ministry of Finance referred to the need for strict fiscal rules to eliminate any remaining 'mistrust against Sweden' (Swedish Ministry of Finance 1998, p. 19; see also Swedish Ministry of Finance 2000b, appendix 2, p. 6).

But the Swedish Ministry of Finance soon emphasized another argument that fiscal contraction measures could be expansionary in the long run: that the elimination of public budget deficits would stimulate growth by a positive relationship between macroeconomic stability and investment (Swedish Ministry of Finance 1999, p. 1; 2000a, p. 23). In fact, the main argument in mainstream macroeconomics that fiscal austerity and fiscal rules are favourable to growth is that they supposedly contribute to macroeconomic stability. Lesser output volatility is assumed to stimulate private investment and consumption by the reduction in uncertainty. In particular, it will weaken the incentive to postpone investment to get more information about profit developments (Dixit and Pindyck 1994). In the theory of rational expectations, any 
endeavour to press down unemployment below the natural rate by expansionary economic policy is not only fruitless, but also associated with larger fluctuations in output (see Friedman 1977, pp. 465-466). Few mainstream economists referred in the 1990s to the risk that that fiscal rules could destabilize the economy by reinforcing a procyclical fiscal-policy pattern, especially if the rules were formulated for the short run and lacked escape clauses. Only in a few passages did the Swedish Ministry of Finance mention that the country's fiscal rules were superior to the SGP rules because of the larger room for discretionary fiscal policy in a recession.

When referring to the positive relationship between fiscal austerity, macroeconomic stability and investment, the Swedish Ministry of Finance probably also assumed that growth is stimulated by price stability. The growth literature considers the possibility that output may be retarded by inflation, particularly through the distortion of relative prices (see Barro and Sala-i-Martin 2004, p. 520). But the adjustment by rational agents to stable inflation, and the non-accommodation policy by the Central Bank (offsetting any tendency to higher inflation) in the new neoclassical synthesis, shifted the focus in this literature to the negative growth effects of variations in inflation. Arguably, it is variations in the rate of inflation that are associated with uncertainty about relative prices. Milton Friedman also emphasized that inflation volatility is associated with the shortening of the optimal length of unindexed contracts having a negative effect on market efficiency (Friedman 1977, pp. 466-467). In the rational expectations theory, inflation volatility is unleashed by profligate fiscal policies.

Some macroeconomists have analysed the relationship between fiscal policy and GDP growth by the use of a Solowian or endogenous growth model. The underlying assumption in the endogenous growth models is that innovation and technological progress are stimulated by investment in $\mathrm{R} \& \mathrm{D}$, physical capital and human capital. Many endogenous growth models provide room for the possibility that fiscal policy may have long-term effects on per capita GDP growth. In Barro (1990), long-term growth can be enhanced by infra-structural public investment. But it may be hampered by public consumption leading to the crowding out or even, as in the financing of the public sector, to the obstruction of private production. The subsequent theoretical development and empirical studies of the relationship between fiscal policy and growth (temporary or permanent) came to focus on the tax structure and the composition of 'productive' and 'unproductive' public expenditure (see, for example, Castro 2007 and Gemmel et al. 2011). In this perspective, the relationship between the fiscal rules and economic growth depends on the design of the rules and the combination of taxes and expenditures to satisfy them.

\section{THE REAL EFFECTS OF FISCAL AUSTERITY IN THE SHORT RUN}

At first sight, Swedish fiscal restraint in 1994-1998 seems to have been neutral or expansionary. There was a sharp decrease in household savings rates in Sweden during this period. ${ }^{7}$ And long-term nominal and also real interest rates fell substantially during the second half of the 1990s - see Figure 1. Real interest rates shrank as the reduction in expected inflation did not match the reduction in nominal interest rates.

Moreover, after having widened in 1994-1995, the gap between long-term interest rates in Sweden and Germany decreased in 1995-1996 - see the comparison of

7. In fact, in 1995-1998, no other OECD country except Italy had as strong a decrease in net household savings rates as Sweden (OECD Economic Outlook 2010, no 2, annex table 23). 


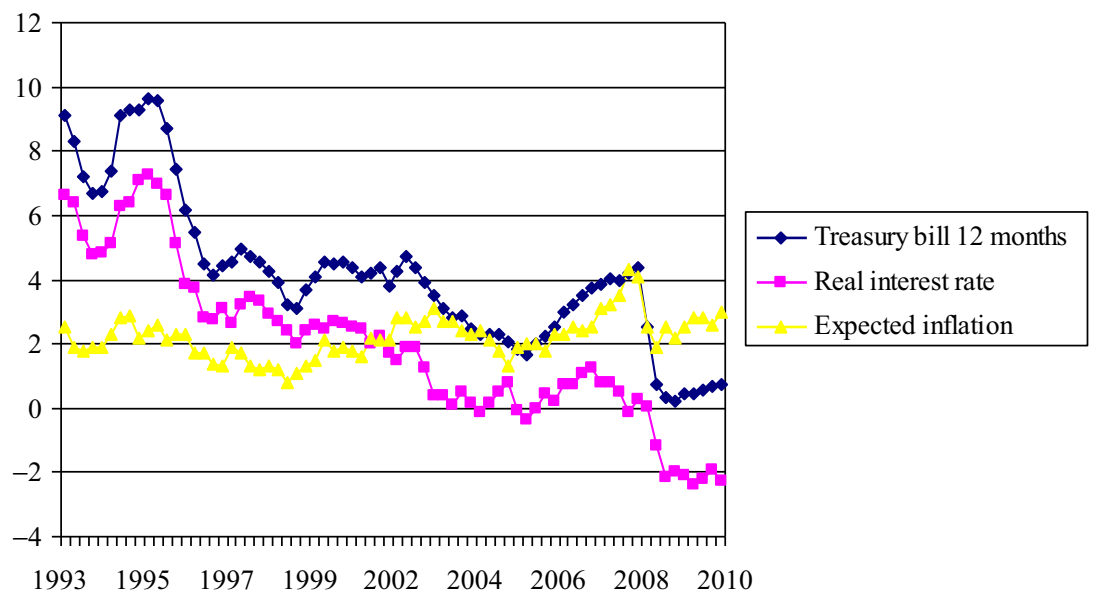

Source: The Riksbank (treasury bills 12 months) and The National Institute of Economic Research (consumer confidence indicators, expected inflation 1 year ahead).

Figure 1 Nominal yield on Swedish treasury bills, expected inflation 1 year ahead by Swedish households and real Swedish interest rates (the nominal interest rate less expected inflation), 1993-2010, quarterly data

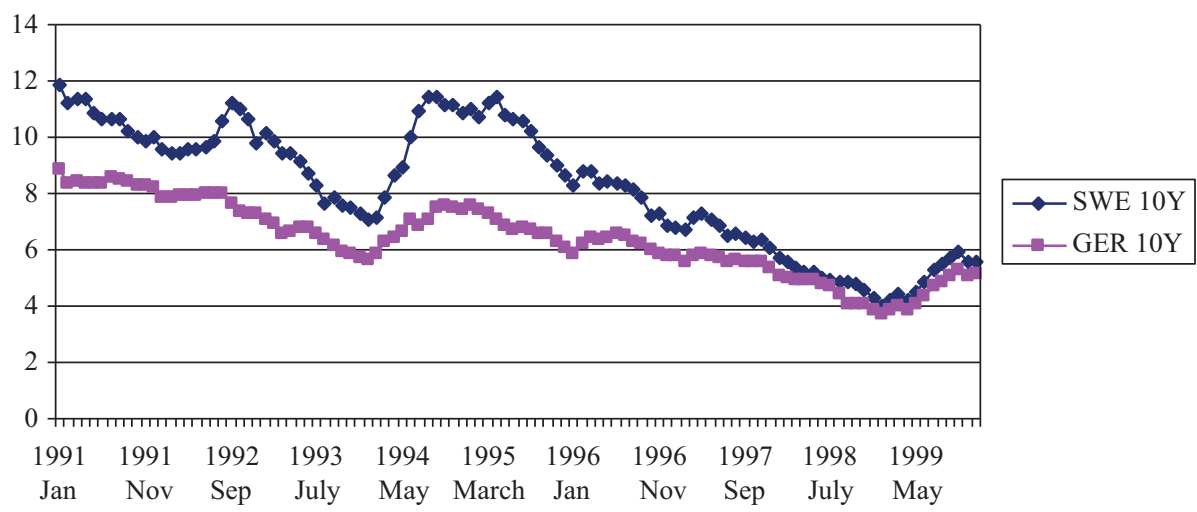

Source: The Riksbank.

Figure 2 Nominal yields on 10-year government bonds, January 1991 to December 1999, Sweden and Germany, monthly data

10-year bonds in Figure 2. In the year 2000, the German-Swedish divergence in bond yields had actually disappeared.

The dramatic reduction in Swedish household savings in 1994-1998 seems a strong case for Ricardian equivalence. But it is extremely difficult to separate the effects of the public budget consolidation and the export-led business-cycle upswing that had already started in 1993. And the development towards lower interest rates (and 
inflation expectations) in Sweden had already begun during the deep recession in the early 1990s. In fact, Swedish interest rates started to converge with the German rates immediately after the exchange-rate turmoil in Autumn 1992 - that is, in a period of increasing public deficits. The growing long-term interest gap between Sweden and Germany in 1994-1995 arose through expectations of an increase in the Riksbank's prime rate, thus it was not directly related to Sweden's public budget deficit. And these expectations were primarily based on the depreciation of the SEK which had led to higher import prices and also to unstable labour markets with overly high nominal wage increases, which is to be expected after a strong depreciation. In the first year with flexible exchange rates (1993), the SEK had depreciated by 25 per cent against the currencies of competing countries, a weakening of the SEK similar to that after the Swedish devaluations in the early 1980s.

This explanation for the larger differentials in interest rates in 1994-1995 between Sweden and Germany is corroborated by the fact that Finland had a similar development in interest rates as Sweden - see Figure 3. Finland had followed the same pattern of financial deregulation and overheating in the 1980s and financial crisis in the early 1990 s as Sweden. Moreover, both countries switched to flexible exchange rates in Autumn 1992 (Finland 2 months earlier than Sweden) and experienced a similar dramatic dip in the value of the currency the following year. But Finnish governments had already undertaken fiscal austerity measures in the early 1990s, thus, unlike Sweden, in the period when the long-term interest gap with Germany started to grow in both countries. ${ }^{8}$

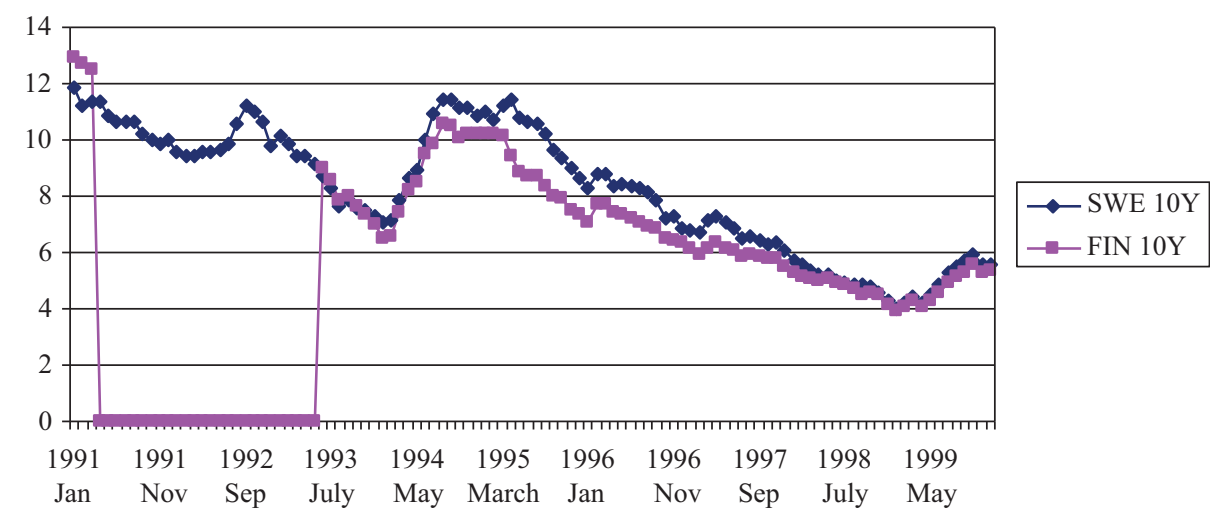

Source: The Riksbank.

Figure 3 Nominal yields on 10-year bonds, January 1991 to December 1999, Sweden and Finland, monthly data

8. The increase in yields on 10-year bonds in 1994 was somewhat stronger in Sweden than in Finland - see Figure 3. The difference in bond yields between the countries in 1994-1995 probably reflected expectations of a lower wage inflation in Finland, inter alia, because of the higher unemployment rate and the stronger coordination of industrial wage negotiations. Actors on financial markets might have been uncertain about the Swedish wage development in the aftermath of the so-called Rehnberg commission, an extraordinary tripartite incomes-policy arrangement in 1990-1992. 
As expected, Swedish monetary policy was tightened in 1994-1995. The ambition of the Riksbank was to combat the inflation tendencies in the wake of the Swedish export-led recovery, and particularly to mitigate the inflation pressure after the weakening of the SEK (the Riksbank 1994, pp. 7-8; 1995, pp. 44-45). Thus, neither the previous increase in long-term yields on Swedish bonds nor the restrictive monetary policy of 1994-1995 revealed a growing mistrust of the ability of Swedish governments to accomplish a public budget consolidation. In fact, the Social Democrats had already begun their frontloaded consolidation policy in November 1994. Besides, an ambitious fiscal austerity programme had already been launched by the non-socialist government at the beginning of 1994.

Similarly, the decreasing gap in long-term interest rates between Sweden and Germany in 1995-1996 was not caused by the ongoing fiscal austerity policy, but by expectations of a decrease in the Riksbank's prime rate. And these expectations were not directly formed by fiscal policy but by the suspicion among speculators (later confirmed) that the SEK would be strengthened in 1995 by a restrictive monetary policy (and improvements in the Swedish trade balance) mitigating the threat to the Riksbank's inflation target.

What is more, the decreasing yields on Swedish treasury bills and government bonds, more than half a year before the switch to a more lax monetary policy in January 1996, cast doubt on the hypothesis that the falling interest rates in Sweden reflected a nexus between front-loaded fiscal restraint and expansionary monetary policy (cf. Ahrend et al. 2006, p. 22; Henriksson 2012). The reduction in the Riksbank's prime rate (the repo rate) in 1996 was primarily a consequence of weaker inflation pressure through the strengthening of the SEK (from mid 1995 until early 1997) and also through unexpected productivity increases in the Swedish economy (in early 1996). ${ }^{9}$ The steady slackening of monetary policy during the second half of the 1990s, notwithstanding a strong recovery of the Swedish economy, reflected a conspicuous productivity development (see next section) and a restrictive monetary policy in the past. Monetary restraint in the first half of the 1990s had succeeded, together with the economic crisis, in bringing down expected inflation and in establishing general confidence in the newly introduced inflation target.

Besides, it is difficult to relate the convergence of Swedish and German long-term interest rates during the second half of the 1990s, and particularly the almost parallel development in these rates since the end of 1996, to Swedish economic policy in any way whatsoever. In the $1990 \mathrm{~s}$, there was a general convergence of long-term real interest rates among the OECD countries, a development that was only temporarily interrupted in the middle of the decade (Laopodis 2002; Brook 2003; Upper and Worms 2003; Afonso and Rault 2010). Thus, falling interest-rate differentials vis-à-vis Germany was not unique for Sweden, which downscales the impact of domestic factors, including the budget consolidation policy. The convergence of interest rates largely reflected the globalization and deregulation of financial markets and the implementation of the Maastricht-SGP integration project per se.

There was indeed a recovery of private investment and consumption in Sweden during the years of fiscal austerity. But the Swedish recovery was not consumptionor even investment-driven. The increase in private consumption in the mid 1990s was similar to that in the upcoming euro countries on average - see the first column in Table 2. And this increase was actually weaker in Sweden than in the small open

9. Also, the Riksbank downplayed the importance of the fiscal austerity policy for lower inflation pressure and expansionary monetary policy in 1996 (see the Riksbank 1996a and 1996b). 
Table 2 Average annual (percentage) changes in real private consumption expenditure and in real total domestic demand, 1995-1997 and 1995-1998 (in brackets)

\begin{tabular}{lcccc}
\hline & Private consumption & \multicolumn{2}{c}{ Private investment } & Domestic demand \\
\cline { 3 - 4 } & & Non-residential & Residential & \\
\hline Sweden & $1.8(2.1)$ & $12.0(11.4)$ & $-8.8(-6.7)$ & $1.6(2.3)$ \\
Denmark & $2.2(2.2)$ & $9.7(10.2)$ & $10.3(8.2)$ & $3.8(3.8)$ \\
Norway & $4.5(4.0)$ & $10.5(11.7)$ & $8.5(8.4)$ & $5.1(5.3)$ \\
Finland & $3.7(3.8)$ & $13.7(13.5)$ & $8.6(8.3)$ & $4.2(4.5)$ \\
Austria & $1.3(1.4)$ & $3.6(4.6)$ & $3.4(1.4)$ & $1.7(1.9)$ \\
Belgium & $1.4(1.8)$ & $5.5(5.6)$ & $2.1(1.4)$ & $1.9(2.3)$ \\
Netherlands & $3.3(3.7)$ & $7.7(7.1)$ & $3.3(3.0)$ & $3.4(3.8)$ \\
Switzerland & $1.1(1.4)$ & $4.3(5.7)$ & $-3.6(-2.0)$ & $0.8(1.6)$ \\
SOWEC & $2.4(2.6)$ & $8.4(8.7)$ & $3.0(2.8)$ & $2.8(3.2)$ \\
Euro area & $1.7(2.0)$ & $4.1(5.0)$ & $1.3(1.3)$ & $1.8(2.1)$ \\
Total OECD & $2.7(2.8)$ & $8.0(8.0)$ & $1.3(1.4)$ & $3.0(3.0)$ \\
\hline
\end{tabular}

Note: a. Small open Western European countries (Sweden, Denmark, Norway, Finland, Austria, Belgium, Netherlands and Switzerland) on average.

Source: OECD Economic Outlook (2004; 2012, no 2, annex tables 3 and 8).

Western European countries and the OECD on average. The Swedish recovery in total investment in the mid 1990s was modest from an international perspective - see columns two and three in Table 2 . There was a significant increase in private investment excluding residential investment in the country (see column three). But the sharpest increase in these investments had already occurred in 1994-1995. Both nominal and real interest rates on Swedish Treasury bills and government bonds did actually increase during the second half of 1994 and the first half of 1995 - see Figure 1.

Swedish investments in the mid 1990s were mainly induced by higher exports, reflecting an international recovery and a profit increase in manufacturing due to the depreciation of the SEK (see next section). ${ }^{10}$ The profit share of value added in manufacturing reached a record level for the postwar period in the mid 1990s. Swedish depreciations largely explain why export growth and the share of the trade balance in real GDP growth in the middle of the 1990s was higher in Sweden than in other OECD countries with the exception of Ireland and South Korea (OECD Economic Outlook 2008, no 2, annex tables 9 and 38).

Thus, in the mid 1990s, fiscal austerity contributed strongly to budget consolidation, but not to the recovery of the Swedish economy. On the contrary, the subdued fiscal (and monetary) policy at that time had contractionary effects, thus causing a delay in the Swedish recovery after the deep economic recession of the early 1990s. During the fiscal consolidation period, domestic-demand growth was low in Sweden from an international perspective - see column four in Table 2. Notwithstanding favourable circumstances such as a weaker SEK (1993-1995), an international recovery and a high potential for Solowian growth (see the absolute reduction in GDP in the early 1990s), Sweden experienced lower GDP growth than the OECD average 1996-1997 (OECD

10. In 1994-1995, the manufacturing sector's share of the increase in total investments at constant prices was between 68 and 79 per cent (depending on the choice of reference year). Between 1994 and 1998, the corresponding shares were 46 and 51 per cent. These shares were disproportionately high considering that the manufacturing sector's share of value added (constant prices) varied between 17 and 20 per cent at the time (OECD 2002 and 2005, table 10). 
Economic Outlook 2008, annex table 1). The improvement in Swedish labour market conditions in 1994-1995 came to a halt during the second half of 1995 when unemployment began to rise, and employment to fall, once again. A sustainable employment recovery (and reduction in unemployment) in Sweden did not occur until the second half of 1997. By a standardized measure, Swedish unemployment peaked in 1997, thus not during the previous recession (OECD Economic Outlook 2012, no 2, annex table 14). Undoubtedly fiscal policy contributed substantially, albeit together with the stronger SEK during the second half of 1996, to the Swedish economic backlash of the mid 1990s. Swedish fiscal austerity in the mid 1990s was definitely a success story from a cameral, although not from a stabilization policy, viewpoint.

At the end of the 1990s, there was a growing insight within the Ministry of Finance that deflationary forces had been too strong in Sweden in the middle of the decade. The civil servants put the blame on the Riksbank - it had not taken the opportunity to ease monetary policy in 1995 after the declarations, and also the beginning, of an ambitious front-loaded fiscal austerity policy (Swedish Ministry of Finance 2000a, p. 41). This argument colludes with the one above, saying that the (front-loading) fiscal consolidation programme induced an actual easing of monetary policy. Both arguments have been challenged in this section. Swedish monetary policy was primarily governed by the ambition (perhaps overambition) to create sustainable confidence in the new inflation target in general, and by variations in the threat to this target from expected or actual changes in the exchange rate in particular. And the changes in the value of the SEK were primarily explained by other factors than the fiscal stance or the plans for, or realization of, a budget consolidation package. Besides, globalization and financial deregulation had narrowed the room for independent monetary policy, particularly in a small open country like Sweden.

\section{THE REAL EFFECTS OF FISCAL AUSTERITY IN THE LONG RUN}

\subsection{An export-, technology- and profit-led economic development}

The fiscal austerity policy during a period of high unemployment, and the creation of new institutions for economic policy-making (the ambitious targets for fiscal and monetary policy, the new budget process at the national government level and the legislation on central-bank independence) are all aspects of the introduction of a new economic-policy regime in Sweden in the 1990s. The new regime seems to have been successful, especially in terms of GDP growth up until the global financial crisis (OECD Economic Outlook 2008; 2014, no 2, annex table 1). For example, despite the country's specialization in telecommunication products, the recession after the ICT crash in the early 2000s became as mild and short-lived in Sweden as in other OECD countries. But the beneficial GDP development in Sweden from the mid 1990s was export-, profit- and technology-led, thus not the result of fiscal austerity in the mid 1990s or the contemporary and subsequent fiscal reforms.

In 1995-2007, Swedish investments were enhanced by an export recovery (through the export multiplier-accelerator), a profit boom (especially in manufacturing), and by major inventions and fierce competition in the ICT sectors, in which Sweden specializes. A weak currency laid the foundation for the Swedish export and profit boom of 1995-2007. The depreciation of the SEK, particularly in 1993 but also in the 2 subsequent years, was followed by a new depreciation in 1997-2001. And Sweden maintained her competitive advantage in terms of the exchange rate (and in terms of relative 
unit labour costs). In 2007 (and also in 2013), the effective (competition-weighted) real exchange rate for Sweden was approximately 26 per cent lower than in 1992, thus immediately before the huge depreciation of the SEK (OECD Economic Outlook 2009, no 1; 2014, no 1, annex table 42). Granger causality tests are (despite the name) an instrument to uncover predictive rather than causal relations. But they support a hypothesis that the weakening (strengthening) of the SEK in 1995-2014 had a positive (negative) effect on Swedish goods export with a delay (after three quarters). This relationship probably reflected the importance of the exchange rate for the relative prices of Swedish products and the profits of the exposed sector. ${ }^{11}$ Moreover, a Granger causality test suggests that the weakening (strengthening) of the SEK produced a positive (negative) effect on profits in Swedish manufacturing after two to three quarters, especially if the years of the global financial crisis are excluded. And changes in the Swedish exchange rates (1993-2004) were not induced by fiscal policy, but by the reaction of monetary policy to asymmetric shocks and, primarily, by speculative capital movements (Alexius and Post 2008).

From the mid 1990s until the global financial crisis, Sweden was in two respects blessed with an advantageous conformation of export. The telecommunication industries made a major contribution to the recovery of Swedish exports during the second half of the 1990s. The share of telecommunications equipment in Swedish export value rose from 9 per cent to 17 per cent in 1995-2000 and the share of Ericsson, the leading domestic producer of telecom products, in Swedish exports was almost 20 per cent in 2000 (Erixon 2011, pp. 309-310). Because of fierce price competition in ICT industries, the increase in the export share of telecom products was even more pronounced in volume terms.

Sweden's export composition was also beneficial in 1995-2007 by means of the country's specialization in raw materials (wood products, iron ore, and iron and steel products) and in investment goods other than telecommunications equipment. Low- and medium-tech industries actually replaced the ICT sector as the Swedish export engine after the ICT crash in the early 2000s. On the strength of their low import share, the raw materials industries (and hence Sweden's net export) benefited specifically from the depreciations of the SEK. And these industries profited from high demand in world markets and from price increases, especially in the 2000s, through the South-East Asian growth miracle. Despite the ICT revolution, in 1995-2007, the export of old products to established (regional) markets constituted a larger share of export growth (value) for Sweden than for 38 other countries, including both OECD members and non-OECD countries, with the exception of China, Brazil and Spain (Beltramello et al. 2012, figure 7).

The partly overlapping, partly sequential, success of the advanced ICT sector and the traditional export industries resulted in a steady increase in the export share of Swedish GDP from the mid 1990s up to the global financial crisis (hitting Sweden during the fourth quarter 2008) with an interruption only during the ICT recession. ${ }^{12}$ Sweden attained a current-account surplus in the mid 1990s. Notwithstanding the negative terms-of-trade effects of telecom product specialization, the Swedish current-account surplus then increased steadily in 1996-2007 (OECD Economic Outlook 2012, no 2, annex table 51). At the time of the outbreak of the financial crisis, Sweden

11. The Granger causality tests presented in this article are based on the first differences of logtransformed quarterly data from the first quarter 1995 until the first quarter 2014.

12. According to the Swedish national accounts, the export share of GDP (constant prices) rose from 26 per cent at the end of 1993 to 35 per cent in late 1997 and to 47 per cent in late 2007. 
had obtained a larger surplus in the current account, as a ratio of GDP, than any other OECD country, with the exception of the oil producer Norway (and Luxembourg). The improvement in the Swedish current-account balance was particularly strong in the 2000s, reflecting, inter alia, the low import ratio of the raw materials industries. In 1995-2007 the net-export share in real GDP growth was high in Sweden compared to that of other OECD countries (OECD Economic Outlook 2008; 2012; 2014, no 2, annex tables 9 and 38).

Furthermore, good productivity performance enlarged the potential for high GDP growth in Sweden in the period 1996-2006. Similarly to other countries with a strong ICT sector (the USA, Finland, Ireland and South Korea), Sweden experienced a 'productivity miracle' during this period. In the second half of the 1990s, telecommunication industries accounted for almost all of the high growth in total factor productivity (TFP) in the Swedish business sector and, in 1993-2005, for 30 per cent of the high labour productivity growth in this sector (Lundgren 2007, pp. 26-30; Edquist 2009, p. 36). Telecommunication industries boosted Swedish productivity growth by the productivity increases within firms and by the industries' increasing share of total employment. In 2000-2005, other industries' use of ICT knowledge made the most important contribution to TFP growth in the Swedish business sector. The Swedish productivity wonder bore hardly any relation to the economic policy (or the monetary and fiscal rules) of the 1990s, but is explained by the country's specialization in industries with large technological opportunities and fierce global competition and, basically, by the early openness of the economy and the salience of cultural and historical factors. ${ }^{13}$

\subsection{A multiple regression study of Swedish investment}

A multiple regression analysis based on quarterly data was intended to define the determinants of real investment in the Swedish business sector, and separately in the Swedish manufacturing sector, in 1995-2014. The investment equation is similar to that in Kalecki (1954 [1965] and 1968). A Kaleckian investment function is assumed to provide a representative picture of the Swedish growth process in the period under review (see the emphasis on profits, technological shocks and the accelerator in this function). By the inclusion of an interest-rate variable, the Kaleckian function can also shed light on a possible positive relationship between fiscal austerity and investment.

The following linear investment equation was tested for the whole Swedish business sector and for Swedish manufacturing:

$$
R I_{t}=\beta_{0}+\beta_{1} E X P_{t}+\beta_{2} P R O F_{t-n}+\beta_{3} A L P_{t-n}-\beta_{4} I R_{t-n}+e_{t},
$$

where $n$ is a number between 1 and 8 defining the time lag structure.

$R I_{t}$ stands for gross physical investment (constant prices) during a specific quarter. $E X P_{t}$ is the volume of Swedish export commodities and services during the same quarter. In the analysis of investment in manufacturing, the focus is on export of commodities only. $P R O F_{t-n}$ is gross profits in value terms where $n$ is allowed to

13. It is uncertain whether the Swedish ICT wonder can be explained by the deregulation wave of the 1990s. The industrial networks around and the spin-offs from Ericsson, established in 1876, were important components of the Swedish innovation system long before the deregulation of the telecommunication sector in the 1990s. 
vary between 1 and 4, thus changes in profit are assumed to influence investment with a delay of one to four quarters. $A L P_{t-n}$ denotes labour productivity, thus value added in constant prices as a ratio of labour hours. The time lag between investment and productivity is assumed to vary from one to six quarters. $I R_{t-n}$ is the real interest rate defined as the nominal yields on 10-year Swedish government bonds less actual inflation or, alternatively, as the nominal yield on Swedish Treasury Bills less expected inflation (see Figure 1). Changes in the interest rates are assumed to influence investment after three to eight quarters. Finally, $e_{t}$ is an error term including omitted variables such as profit taxes. ${ }^{14}$

The export variable is included to envisage the impact of the accelerator on investment in the Swedish exposed sector (which is approximated with Swedish manufacturing) and the short-run export multiplier in combination with the accelerator in other parts of the Swedish economy. The profit variable is meant to capture the salience of static expectations (expected profits are based on actual profits) and retained earnings for investment. The gross-profit measure makes it possible to illuminate the importance of investment to replace worn-out capital (depreciations). The productivity variable represents technological shocks and exogenous R\&D investment. Physical investment might be promoted by an increase in productivity per se but also, indirectly, by a positive effect on profit and export. In the export case, higher productivity, especially in manufacturing, might result in a cost advantage for Swedish companies. The final inclusion of the interest rate makes it possible to test the idea that fiscal restraint can be expansionary by having a negative effect on the long-term interest rates. ${ }^{15}$ The extraordinary fiscal-consolidation programme in the mid 1990s and the permanent consolidation programme formed by the fiscal rules might have led to falling real interest rates in Sweden, inter alia by a reduction in the risk premium on government borrowing, in 1995-2014. The reduction in the interest rates is supposed to have stimulated Swedish investment directly, but also by inducing a weakening of the SEK, having a positive effect on exports.

The definition of the time lag structure was based on Granger causality tests, but also on some reasonable assumptions about the underlying causal relations. For example, the time delay between productivity and investment was assumed to be possibly longer than that between profits and investment; a productivity shock may affect investment by inducing a change in profit. The determination of the lag structure was also based on the results from earlier empirical studies. The exact time-lag structure was ultimately settled by a tentative multiple regression procedure.

14. The statistics on investment, value added, labour hours, gross profit and export have been taken from the national accounts (Statistics Sweden). Data on inflation were obtained from Statistics Sweden, on nominal interest rates from the Riksbank and on expected inflation and exchange rates (KIX index) from the National Institute of Economic Research (Konjunkturinstitutet). The KIX index considers changes over time in the country's trade pattern.

15. The main difference between the investment theory in Kalecki (1954 [1965]) and the theory underlying equation (1) above is that the latter theory emphasizes the importance of the export multiplier-accelerator in a small open economy. Furthermore, in Kalecki's investment equation, profits and gross savings (largely determined by gross corporate saving) are deflated by a price index for investment goods. Investment-goods prices are considered in the robustness tests. Besides, the profit variable in equation (1) is meant to indicate the importance of both retained earnings and static expectations for private investment. In Kalecki's investment equation, (changes in) profits are intended to capture the accelerator mechanism (Kalecki 1954 [1965], pp. 97-106). 
Table 3 The determination of investment in the Swedish business sector, 1995Q12014Q1, OLS regression, logarithmic transformation, first differences

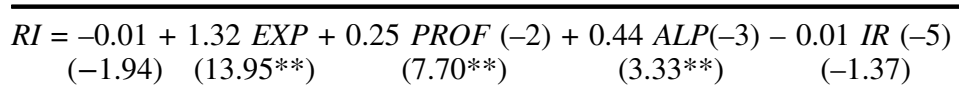

Number of observations: 77; adjusted $R$-squared: 0.91; Durbin-Watson statistics: $2.33 ; F$-statistics: 184.48. Notes: $t$-statistics are presented in the parentheses. ** Significance at $1 \%$ level. RI: Gross physical investment (constant prices); EXP: Swedish export (constant prices); PROF: gross profit (value); ALP: labour productivity; $I R$ : real interest rate (yields on 10-year government bonds less actual inflation).

The estimates of the coefficients $\beta_{0}$ to $\beta_{4}$ in equation (1) are based on the first differences of log-transformed raw data. (To avoid negative values, a proper positive number has been added in the case of the real interest rates.) The results from the OLS regressions for the Swedish business sector in 1995 Q1 to 2014 Q1 are presented in Table 3.

The OLS regression shows that investment in the Swedish business sector in 1995-2014 was determined mainly by export but also by actual profit and productivity with a lag (two and three quarters respectively). ${ }^{16}$ As expected, the relation between investment and the real interest rate (after five quarters) was negative. But the coefficient was low and insignificant. Regressions based on the alternative real interest rate variable gave the same results. Thus, the investment study provided weak support for the hypothesis that fiscal austerity stimulates economic growth through the interest-rate mechanism. And there were no indications at all of a negative relationship between the nominal interest rates and investment (these results are not reported in Table 3). This is a conspicuous result in light of Granger causality tests showing (as expected) that an increase (decrease) in the nominal interest rates was followed by a strengthening (weakening) of the SEK in the same quarter or after one to two quarters, in 1995-2014.

The main difficulty with the OLS regressions above is interpreting the causality between investment and export during the same quarter. It cannot be taken for granted that a strong correlation between export and investment during the same quarter (as in this case) reflects that export is exogenous. A contemporaneous positive relationship between the two variables may reflect that the export sector is enlarged by investment, particularly in manufacturing. ${ }^{17}$ A Hausman specification test confirmed the suspicion that the OLS estimates in Table 3 hide a simultaneity problem. At the Hausman test, two determinants of Swedish export were used as instrumental variables, the import of goods and services (volume) in total OECD (IMF data) and the competition-weighted exchange rate for Sweden (among the variables in the study, only the interest rates had a significant effect on the Swedish exchange rate in the period under scrutiny). ${ }^{18}$

16. The robustness of the regression results were examined by substituting commodity exports for total exports. This substitution is motivated by the leading role of the (exposed) manufacturing sector in the Swedish economy. However, the regression results were not altered in a significant way. The strength and significance of the relationships were exactly the same when the profit measure was deflated by an investment-goods index (national accounts).

17. A Granger-Sims test of the lag and lead structure gave no guideline for the definition of the exogenous variable in the relation between export and investment.

18. According to the Hausman test, the residual in the reduced-form regression was statistically significant at the 5 per cent level when added to the regression model (see Table 3 ). Thus, there are clear indications of a simultaneity problem in the OLS regressions. 
Table 4 The determination of investment in the Swedish business sector, 1995Q12014Q1, 2SLS regression, logarithmic transformation, first differences

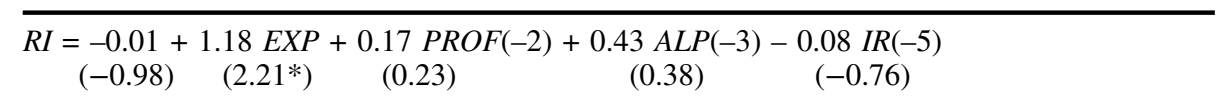

Instrument variables: world import to the OECD (instantly and with a 1-2 quarter delay) and exchange rates (with a one quarter delay).

Number of observations: 76; adjusted $R$-squared: 0.82; Durbin-Watson statistics: 2.28; $F$-statistics: 4.27. Notes: $t$-statistics are presented in the parentheses. * Significance at $5 \%$ level. Standard errors were adjusted for heteroscedasticity after a White test.

$R I$ : Gross physical investment (constant prices); EXP: Swedish export (constant prices); PROF: gross profit (value); $A L P$ : labour productivity; IR: real interest rate (yields on 10-year government bonds less actual inflation).

The clear indications of a simultaneity problem made it necessary to check the OLS results by a regression study based, for example, on the method of two-stage least squares (2SLS). The results from the 2SLS regression of Swedish investment in 1995-2014 are shown by Table 4.

Unsurprisingly, the effect of export on investment was weaker in the 2SLS regression. But the relative importance of the explanatory factors was the same. For example, the real interest coefficients were still low. The low efficiency of the 2SLS estimates (see $t$-statistics) is probably explained by the presence of multicollinearity.

The regression results are almost the same if we cut the time series at 2008 to elaborate the determinants of Swedish investment before the outbreak of the global financial crisis (the results for the 1995-2007 period are not shown). ${ }^{19}$ In the shorter period (1995-2007), the positive effect of labour productivity on investment was stronger in the 2SLS regressions and faster (one instead of three quarters) in both the OLS and the 2SLS regressions. The quicker and stronger effect of productivity changes on investment in this period probably reflected the impact of the ICT revolution in Sweden.

The regression results for manufacturing confirm in the 2SLS case that the relation between investment and productivity was stronger in 1995-2007 than in 1995-2014 (the regression results for manufacturing are not presented). However, investment in manufacturing reacted fast to productivity changes (after one quarter) even when the regressions cover the years of the global economic crisis (2008-2014). A striking result in the 2SLS case is that there was no sign of that investment in manufacturing being stimulated by goods export (or total export). Thus, the strong contemporaneous relation between investment in manufacturing and export since the mid 1990s seems to reflect that higher investment led to higher export and not the other way round. But more importantly, the relationship between investment in manufacturing and the interest-rate variables was very weak and in some cases even positive. Accordingly, the interest-rate variables (nominal or real) were dropped from the investment equations for Swedish manufacturing (see Table 4).

The minor impact of long-term interest rates on Swedish investment is critical for the hypothesis that Sweden's favourable economic development, especially in 19982007, reflected fiscal restraint. The multiple regression study vindicates that Swedish growth since the mid 1990s has been profit-, export- and technology- (productivity-)

19. The extension of the precrisis period to the third quarter 2008 (when Lehman Brothers collapsed) did not affect the regression results more than marginally. 
led. Furthermore, a Johansen cointegration test displayed a long-run relationship (in 1995-2014) between investment and labour productivity, export and profit respectively (mostly at the 5 per cent level), although in the profit case for manufacturing only. ${ }^{20}$ All Johansen tests in the study were based on log-transformed (quarterly) level data. The tests were consistently preceded by a Dickey-Fuller test of unit roots confirming the necessary requirement that variables are non-stationary at levels and stationary in first differences.

The reciprocal relation between export and investment in the Swedish business sector in the study above verifies the results from an earlier (bivariate) study of the relationship between export and growth in 25 OECD countries in 1960-1997. On the basis of different unit-root and cointegration tests and also on various tests for Granger causality, the OECD study disentangled an unambiguous two-way relation between export and growth, but only for Sweden and the UK (Kónya 2004).

\subsection{The subordinate role of fiscal policy}

There is as yet no evidence that the high GDP growth in Sweden from the late 1990s up until the international financial crisis (or the relatively high Swedish growth during the crisis) was caused by the country's fiscal policy and the underlying fiscal rules. But hitherto we have ignored the possibility that (i) fiscal austerity stimulated Swedish GDP growth by the positive effect of lower interest rates on private consumption; (ii) fiscal consolidation in the mid 1990s and the design of the fiscal rules paved the way for an expansionary fiscal policy in recessions; (iii) the fiscal rules led to higher investment (and thus to higher GDP growth) by a reduction in output and inflation volatility; and (iv) the composition and financing of the fiscal austerity measures had a positive effect on Swedish growth.

The first argument (i) is supported by the fall in Swedish long-term nominal and real interest rates during the first half of the 2000s - see Figure 1. The radical fiscal rules (and the fiscal consolidation in the mid 1990s) might have convinced financial actors that Swedish politicians had abandoned an easy-going fiscal policy forcing the Riksbank to implement a restrictive monetary policy. And the fiscal commitments could directly have induced a less restrictive monetary policy. In fact, during the first half of the 2000s, the Riksbank's prime rate was first stable and then decreasing (see the Riksbank's home page).

The lower interest rates in Sweden could have stimulated private consumption (and investment) and thus contributed to the high GDP growth in 1998-2007, although the theory about the neutrality of money denies that monetary policy has real effects in the medium term. But a change in (real) interest rates has ambiguous effects or no effect at all on private consumption in intertemporal-optimizing and Keynesian models (Carlin and Soskice 2006, pp. 212-214). Moreover, it is difficult to explain Sweden's favourable economic development in 1998-2007 by reference to interest-rate development. The long-term yields on Swedish government bonds were close to the corresponding international yields. The parallel development in long-term interest rates challenges the view that fiscal austerity in Sweden reduced the risk premium on government borrowing. From mid 2001 to mid 2005, the Swedish

20. The results from the study of the long-run relationship between interest rates and investment (with a one to five lag interval) were ambiguous. They depended on the choice of study object (the business sector or manufacturing), the time period (1995-2014 or 1995-2007) and the choice of interest-rate variable. 


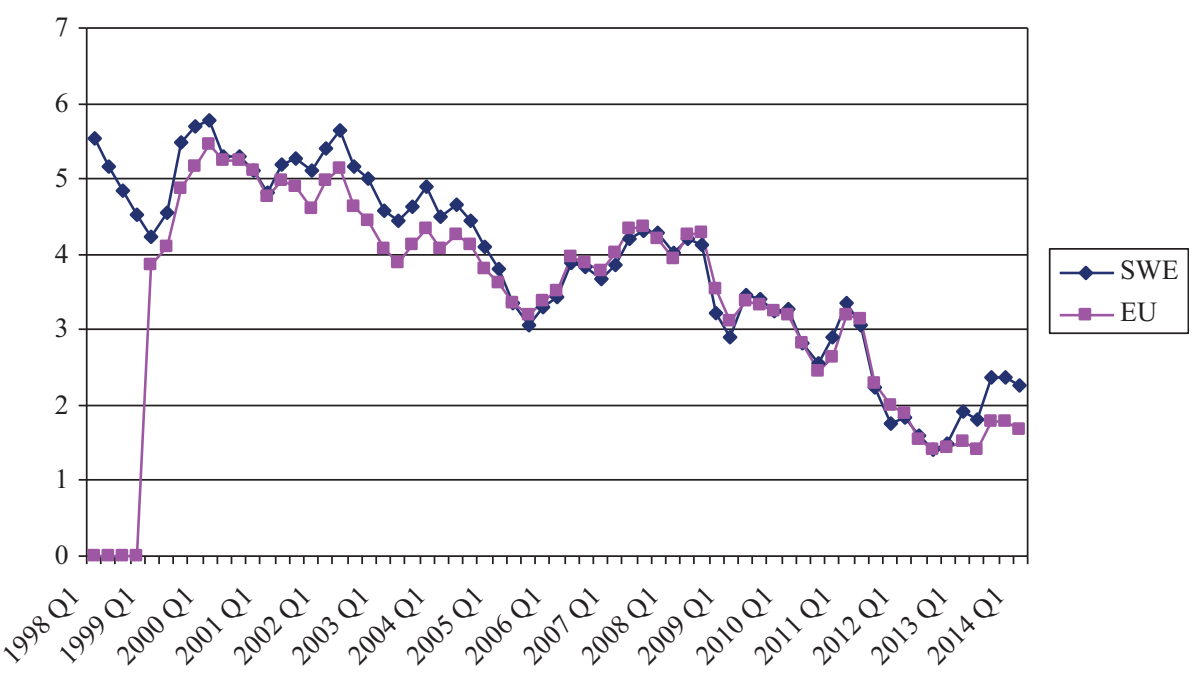

Source: The Riksbank.

Figure 4 Nominal yields on 10-year Swedish (SWE) and Euro (EU) government bonds 1998-2014, quarterly data

long-term interest rates were even somewhat higher than, for example, the yields on long-term Government Euro bonds - see Figure 4. Furthermore, the absence of a restrictive monetary policy in Sweden during the first half of the 2000s largely reflected lower import prices and positive productivity shocks, not fiscal austerity (Söderström and Vredin 2013). What is more, the steady decline in private consumption as a ratio of GDP in 1998-2007 (with a modest increase only during the ICT recession) weakens the argument that Swedish growth was consumer-driven. ${ }^{21}$

On the other hand, the consolidation programmes in the mid 1990s might have created, as the fiscal rules, confidence in Swedish fiscal policy and also a public budget surplus facilitating an expansionary fiscal policy during the ICT recession in the early 2000s (see argument (ii) above). In fact, the easing of Swedish fiscal policy in 2001-2002 was exceptional in an international perspective.

The absence of substantially higher interest rates in Sweden than in other countries in the early 2000s (see Figure 4) might have reflected that the financial markets were convinced that an expansionary fiscal policy in a recession was temporary and thus no departure from fiscal austerity. Fiscal contraction during the second half of the 1990s was the most important explanation for why Sweden could enter the ICT recession with a significant public budget surplus. Initial budget surpluses made it possible to combine a strong counter-cyclical policy with a budget deficit that was actually much smaller than the short-run SGP requirement (3 per cent). However, the importance of the design of the fiscal rules for the easier fiscal policy in Sweden in the early 2000s shall not be exaggerated. Fiscal expansionism was not explained by a conviction among (Social Democratic) politicians and financial actors that the rules for the

21. At the end of 1993, the share of private consumption (including of imported goods and services) of GDP was 89 per cent. This share shrank to 82 per cent in late 1997 and to 74 per cent in late 2007 (Swedish national accounts). 
budget balance were followed in the medium term, which was impossible to have any clear opinion about. The looser fiscal policy in Sweden in the 2001-2002 recession is, rather, explained by the fiscal austerity measures in the mid 1990s (building up a large financial saving) and by the political business cycle. The political motives for the Social Democratic government to pursue a more lax fiscal policy before the 2002 election coincided with the need for fiscal stimuli in a recession. Fiscal policy (for general government) was also expansionary in the election years 1998 and 2006, when Sweden experienced a recovery.

It is still possible that the radical Swedish fiscal rules, providing a room for countercyclical policy, might have created favourable growth conditions in 1998-2007 through the positive effects on macroeconomic stability (see argument (iii) above). However, empirical studies of Sweden and other OECD countries based on GARCH models have provided weak support for the hypothesis that output variation is negative for growth (Grier and Perry 2000; Grier et al. 2004; Fountas and Karanasos 2007; Ljungberg Ording 2014). And the empirical literature about the impact of fiscal rules on the cyclicality of fiscal policy is inconclusive (see Debrun et al. 2008).

It seems likely that fiscal targets will stabilize fiscal policy when the target for the budget balance is defined in the medium term as in the Swedish case (ibid., pp. 313 and 338-342; Combes et al. 2014, p. 3). Despite the political business cycle, Swedish fiscal policy actually displayed a counter-cyclical pattern in $1998-2007 .{ }^{22}$ However, in a study showing that the fiscal rules have mitigated output fluctuations in most OECD countries, Sweden and Switzerland were exceptions to the rule; a limitation of the study is that it only covered the 1980-2002 period (Badinger 2009, p. 841). Moreover, in 1998-2007, economic fluctuations (the standard deviation of the output gap) were larger in Sweden than in the other Nordic countries and also than in the small open Western European countries on average (Erixon 2011, p. 302). Besides, the countercyclicality of Swedish fiscal policy in 1998-2007 (annual data) is no more than close to being significant (at the 10 per cent level). Thus, the impact of the fiscal rules on output volatility is probably of peripheral interest when the relatively high GDP growth in Sweden in 1998-2007 is to be explained. This subordinate role for the Swedish fiscal rules is obvious even if they provide larger room for counter-cyclical fiscal policy than, for example, the corresponding rules for the EMU countries.

The argument that the fiscal rules had positive effects on investment and consumption in 1998-2007 by dampening the fluctuations in the Swedish inflation rate (see argument (iii)) seems more valid. Many cross-sectional, panel and GARCH studies have confirmed that economic growth is obstructed by inflation volatility (see, inter alia, Grier and Perry 2000; Bassanini and Scarpetta 2001; Grier et al. 2004; Castro 2007) and also that inflation volatility is boosted by discretionary fiscal policy (Rother 2004). There was a substantial reduction in inflation volatility in Sweden in 1998-2007. However, this development primarily reflected the absence of strong negative supply and demand shocks (until 2007) and the disciplinary role of the Riksbank's inflation target, inter alia, putting a clear restriction on discretionary fiscal policy. The fiscal rules may have contributed to lower inflation variability in Sweden in 1998-2007, but only in interaction with the inflation target (cf. Combes et al. 2014). And it remains to pinpoint the importance of the lesser inflation volatility for private consumption and investment in Sweden in the period under discussion. A recent bivariate study based on the

22. The cyclical pattern in fiscal policy was estimated by the use of annual OECD data over output gaps (OECD Economic Outlook 2014, no 1, annex table 10) and the general government underlying primary balance (ibid., table 30 ). 
GARCH-M model and monthly data showed that inflation volatility was positive for Swedish production growth in 1960-2013 (Ljungberg Ording 2014).

The subordinate role of the fiscal rules for the high GDP growth in Sweden in 1998-2007 is also obvious in the analysis of the effects of low inflation per se. ${ }^{23}$ Sweden has had very low rates of inflation since the mid 1990s. In fact, in 19952007 (and also in 1995-2013), inflation (annual averages) was lower in Sweden (and Japan) than in all the other OECD countries including the other small open Western countries with the exception of Switzerland. The low inflation in Sweden is explained by the country's strict inflation target compared to many countries outside the EMU (and the UK) and by the Riksbank's deviation downward from its inflation target (2 per cent). Sweden (and Norway with an inflation target from 2001) seems to have deviated more from the target than other OECD countries. Besides, Sweden (and Norway) undershot rather than overshot the target in contrast to other OECD countries with flexible exchange rates (Andersson et al. 2012; Svensson 2015). The strictness of the inflation target and the deviations from it since the mid 1990s explain why Sweden moved down the Phillips curve to a larger extent than, inter alia, the USA and the other small open Western European countries (excluding Finland) on average. The position, and in fact also the slope, of the Phillips curve for Sweden were fairly similar to those for the other small open Western European countries. Thus, Sweden displayed high unemployment and low inflation in comparison with similar countries (Erixon 2011, pp. 304-305; Svensson 2015). ${ }^{24}$

Moreover, the Riksbank's systematic deviation downward from its inflation target cannot be derived from (unpredicted) fiscal austerity measures. It was a consequence of unanticipated positive productivity shocks and reductions in import prices (Söderström and Vredin 2013) and overly strong ambitions to fight inflation, as well as of the Riksbank prioritizing other goals than inflation, primarily stable housing and financial markets (Svensson 2015).

It remains to draw conclusions about the growth effects of the composition of taxes and public expenditures during the period of fiscal austerity in Sweden (see argument (iv) above). Up until the global financial crisis, Swedish fiscal policy obstructed growth by the salience of tax increases in the budget-consolidation programmes (Swedish Ministry of Finance 2000a, p. 28; Claeys 2008, pp. 29-30; Reicher 2013, table 2). But fiscal policy was neutral or positive for Swedish growth by the lesser use of distortionary taxes (primarily corporate and personal income taxes) and the increase in expenditure on welfare provisions and education (Gemmel et al. 2011). This ambiguity is critical for the argument that the high GDP growth in Sweden in 1998-2007 is explained by the fiscal policy and the underlying fiscal rules. ${ }^{25}$

23. Empirical studies actually provide weak support, at least when countries with hyperinflation are excluded, for the hypotheses that growth is promoted by low inflation per se (Barro and Sala-i-Martin 2004, pp. 532-533; Rother 2004, pp. 7-10).

24. The conclusions about the Phillips curves above are independent of whether the estimates of Swedish inflation are based on a consumer price index or on a harmonized index of consumer prices (as in the OECD statistics for the euro countries and the UK). And the conclusions are independent of whether the studies are based on annual or quarterly data, estimations of Phillips curves in the short or long run, and whether the inquiries cover the global financial and debt crisis or not.

25. A regression study of 17 OECD countries showed that fiscal changes in 1990-2002 had stronger positive effects on GDP growth in Sweden than in any of the other countries ( 0.5 percentage points per year on average). A reference was made to the reduction of distortionary taxes (personal income, payroll and profit taxes in particular) and the increase in productive public 
To sum up, there is scant evidence that Sweden's high GDP growth from the mid 1990s until the late 2000s reflected the positive effects of the country's fiscal rules on private consumption through the interest-rate mechanism. And the rules were not decisive for the easing of fiscal policy in the recession in the early 2000s. Nor can the design of the Swedish fiscal rules be unambiguously thanked for the high GDP growth in the country in 1998-2007 by reference to its impact on output fluctuations and the composition of public expenditure and taxes. Furthermore, the argument that the fiscal rules have stimulated growth by the effects on inflation and inflation volatility is a doubtful one, particularly in light of the sovereignty of the Riksbank's inflation target. This does not deny that Swedish fiscal policy could have been more expansionary if the fiscal rules had been less strict. Such a policy was made possible by the actual deviations from the inflation target by the Riksbank. Swedish fiscal policy could also have been more expansive if the inflation target for the Riksbank had been less ambitious (Lundborg and Sacklén 2006).

\section{SWEDISH FISCAL POLICY DURING THE FINANCIAL CRISIS}

Sweden entered the global financial crisis in 2008-2009 with a large public budget surplus (3.3 percent of nominal GDP in 2007 according to OECD Economic Outlook 2014, no 2, annex table 27). The budget surplus at that time was not unique for Sweden; in fact it was much smaller than that in the other Nordic countries. Moreover, the Swedish budget surplus was actually somewhat smaller in 2006-2007 than in 1989-1990, thus immediately before the deep financial crisis in the early 1990s and well before the introduction of the fiscal rules. But during the first years of a nonsocialist government, the Ministry of Finance leaned towards the conclusion that Sweden had achieved its medium-term budget target (Swedish Ministry of Finance 2007, ch. 4, pp. 79-80). Furthermore, the general opinion among politicians and economists in Sweden in the mid 2000s was that the public budget surpluses after the ICT recession in the early 2000 s, and the steady reduction in public debt since the mid 1990s, had convinced financial investors that the fiscal rules had been followed and that any public deficit was only temporary. The non-socialist government seemed to be convinced that the large surplus in the general government finances provided room for fiscal stimulus (Government Offices of Sweden 2014, p. 18). At the beginning of the global financial crisis, the Minister of Finance declared his affiliation to Keynesian discretionary policy, and he also took fiscal actions to stimulate the economy (Swedish Ministry of Finance 2009, pp. 16-17 and 43-47). The need for fiscal stimuli was obvious in 2009 when Sweden experienced a dramatic fall in exports.

However, in 2009, Swedish fiscal policy was pro-cyclical even when net interest payments are included in the cyclically-adjusted general government balance (OECD Economic Outlook 2014, no 2, tables 28-30). The cautious fiscal policy in Sweden in this year, despite an extensive working tax credit programme (following up the similar programmes in 2007-2008), actually had no correspondence in other OECD countries, with the exception of Luxembourg, Estonia and Hungary. At the same time, fiscal built-in stabilizers seem to have been stronger in Sweden than in

expenditure in Sweden (Gemmell et al. 2007). However, the study only covered a few years under the new rule-based fiscal regime. And it only considered two control variables (private investment and employment growth), excluding, for example, the importance of export and productivity shocks in the Swedish case. 
other OECD countries, primarily reflecting the country's large public sector and social insurance system (OECD 2009, ch. 3, figure 3.1). In fact, at the beginning of the financial crisis, a negative correlation could be observed between the scope of the fiscal stimulation programmes and the size of the automatic stabilizers in the OECD countries (ibid., figure 3.5). But fiscal multipliers could not prevent a substantial fall in Swedish GDP in 2009, although the fall was not exceptional from a Nordic perspective (ignoring Norway).

Primarily as a consequence of new working tax credit allowances, fiscal policy in Sweden was pro-cyclical in 2010-2011 when the export sector once again served as a source of momentum for the Swedish economy. In the following years, fiscal policy was approximately neutral or weakly counter-cyclical, at least up until the 2014 election. The general government balance was predominantly negative in Sweden in 2009-2014, reflecting the impact of negative built-in stabilizers, although the deficit never exceeded 2 per cent in relation to nominal GDP. The demanding public budget target for the medium term became a straitjacket for Swedish fiscal policy during the prolonged European debt crisis. Between January 2009 and May 2015 the monthly unemployment rate in Sweden fluctuated between 7 and 10 per cent (Statistics Sweden).

It can be argued, in alignment with the theory of expansion through fiscal restraint, that the cautious fiscal policy in Sweden during the global financial and debt crises kept the long-term interest rates down. However, in 2008-2014, the Swedish long-term interest rates were similar to, or higher, than the international rates - see Figure 4.

The relatively high GDP growth in Sweden since the outbreak of the global financial crisis can largely be attributed to the lack of a bursting housing bubble and an associated bank crisis; that is, Sweden was only hit by the financial crisis through the export channel. European countries suffering from a collapse of the housing and financial markets experienced a deep recession and an automatic increase in the public budget deficit even if they had a significant public budget surplus (and even modest government debts) to begin with (see Iceland, Ireland and Spain in particular). Given the strong public built-in stabilizers, Sweden would not have been able to reach her ambitious fiscal targets if the country had been hit by a domestic financial and banking crisis.

It cannot be excluded that the fiscal rules might have contributed to the absence of a financial crisis in Sweden at the end of the 2000s by having built up confidence for Swedish assets among financial speculators during the decade. But more importantly, in the mid 2000s, the independent Swedish monetary policy made it possible to efficiently counteract overheating tendencies on housing and real-estate markets similar to those in Spain, Ireland and also in Denmark with its fixed exchange rate vis-à-vis the euro. Sweden could also avoid a bank crisis by luck. Because of the deep recession in the Baltic states, the country was on the brink of a bank crisis in 2008-2009. Two of the four leading Swedish banks (SEB and Swedbank) were heavily exposed to the Baltic countries. These banks were lucky enough to escape a liquidity crisis because of the rapid recovery of the Baltic countries. ${ }^{26}$

26. By large borrowing abroad, high market concentration (four-bank domination) and extensive transactions between the domestic banks, the Swedish bank sector is extremely vulnerable to financial disturbances. Sweden is also vulnerable to a banking crisis because of the large size of the bank sector (third in Europe). Moreover, despite the financial crisis in the early 1990s, Sweden did not build up institutions and instruments to prevent a bank crisis until the late 2000s. The necessary 
Moreover, the crisis in Swedish manufacturing was moderated by a weakening of the SEK in late 2008 and early 2009. Owing to its specialization in business-cyclesensitive products, Sweden was hit particularly hard by the global financial crisis. As expected, the SEK was then strengthened during the rapid Swedish export recovery in 2010, although the value of the SEK (and the Swedish effective exchange rates) continued to increase during the following years (at least until the beginning of 2014), thus when the eurozone crisis was getting worse.

The specialization in low- and medium-tech raw materials and investment goods was a clear advantage to Sweden when the EU (particularly the German) and the USA markets recovered in 2010. The traditional Swedish export industries were particularly important for Sweden during a period when the ICT sector was no longer able to serve as an export and productivity engine in the Swedish economy. By her industrial composition Sweden could, inter alia, benefit from the steady growth of the South-East Asian countries. In 2010-2011, for the first time in the history of Swedish industrialism, other countries than the US and the large Western European countries made a major contribution to a Swedish export recovery. Mainly by the export to China, the Asian share of Swedish export (value) increased from 9.7 per cent in 2007 to 12.8 per cent in 2011. Moreover, in 2011 the oil-producing neighbour country Norway replaced Germany as Sweden's main export market (National Board of Trade 2013; 2014). However, in the new European recession in 2012-2014, the export composition became once again (together with the strengthening of the SEK) a disadvantage to Sweden. During this period, Swedish aggregate demand was, in fact for the first time since the 1980s, primarily kept up by an increase in private consumption. But this increase was not primarily the result of an expansionary fiscal policy but by an easier monetary policy. Because of the high prime rates during the strong recovery in 2010-2011 there was an ample room during the eurozone crisis for reductions of this rate down to zero in Sweden. The Swedish prime rate was reduced to 0.25 per cent in July 2014, a rate that had been set exactly 1 year earlier by the ECB.

The relatively high GDP growth of Sweden in 2008-2013 can largely be attributed to the substantial increase in the country's labour-force participation rate (OECD Employment Outlook 2014, table C). This increase was not explained by fiscal stimulus to aggregate demand, but by the labour-supply effects of extensive immigration and, possibly, of the working tax credits and the less generous social-security benefits under the non-socialist regime (2006-2014). ${ }^{27}$

To summarize, fiscal policy played a minor role for the relatively favourable economic development in Sweden in the years after the outbreak of the global financial

capital requirement was probably not met by the Swedish banks in 2008-2009 (the Riksbank 2011). But Sweden could escape a banking crisis through the quick recovery of the Baltic countries, which partly was based on supportive loans from the IMF, the World Bank, the EU and the Nordic countries. The Swedish banks were particularly favoured by the decision of the Baltic governments to avoid currency devaluations. The major part of the bank loans to the Baltic households and companies in the 2000s had been taken out in euros.

27. In fact, extensive immigration and the associated decline in the share of the working-age population in total population explain why Sweden's economic performance was worse in terms of GDP per-capita growth than in terms of GDP growth in 2008-2013 (Erixon 2013, table 6.1). In fact, annual growth in Swedish GDP per capita was on average negative in this period (see estimates by the World Bank of the annual growth of GDP per capita in constant national prices). However, per-capita GDP growth in 2008-2013 was still higher in Sweden than in most other EU countries and also than in the other Nordic countries (and the small open Western countries on average). 
crisis. The fiscal rules, together with the reduction of public debt, might have convinced central actors on financial markets that the time for lax fiscal policy was over in Sweden. But other factors than low long-term interest rates were decisive for the relative success of Sweden, namely her independent monetary policy, inter alia, counteracting the tendency to a commercial real-estate and housing bubble up until the global financial crisis, and her flexible exchange rates, counteracting the crisis for the export sector in 2008-2009. Sweden's relatively good growth performance in 2008-2013 can also be attributed to luck (see the rapid recovery of the Baltic countries).

\section{CONCLUSIONS AND ASSESSMENTS}

The fiscal austerity policy and fiscal rules that were adopted by Sweden in the 1990s were, from an international perspective, radical. By its scope and implementation, in the wake of a deep recession, and in a country and by a party traditionally associated with full employment, fiscal austerity was a noteworthy Swedish experiment in the mid 1990s. The tight fiscal policy pursued by the Social Democrat Minister of Finance Göran Persson (Prime Minister from March 1996) was largely based on a cameral concern for budget balance, and a political fear of being in the hands of foreign asset holders. But the restrictive fiscal policy was legitimized by Persson's economic experts in the Ministry of Finance, who referred to theories about the neutral or even expansionary effects of fiscal austerity.

This article maintains that fiscal austerity in the mid 1990s was not responsible for the strong Swedish recovery in the short term. On the contrary, the restrictive fiscal policy actually delayed Sweden's recovery from the deep crisis of the early 1990s. The reduction in the long-term (real) interest rate on Swedish government assets during the second half of the 1990s primarily reflected an international convergence process, and anticipated changes in Swedish monetary policy unrelated to fiscal policy. Fiscal austerity had already made a significant contribution to the achievement of a public budget balance in 1998. But the depressing conclusion for countries like Greece, Spain and Portugal is that Swedish fiscal restraint in the mid 1990s did have contractionary effects and that the specific external, industry-structural and exchange-rate conditions for a similarly rapid economic recovery - a sustainable international recovery, a strong manufacturing sector and a national currency - simply do not exist in these countries.

It shall not be denied that the financial markets might have needed a signal of Swedish fiscal restraint in the mid 1990s. Sweden had recent experiences of high inflation and large public deficits, and the inflation target for the Riksbank was new. But fiscal policy certainly became too restrictive. Not only did fiscal austerity delay the Swedish recovery after the deep crisis in the early 1990s; employment cuts through rationalization in municipalities and counties also reduced the quality of the welfare programmes, and led to a deterioration in health status of the female employees in the public sector. In 1998-2002 there was a dramatic increase in the amount and duration of reported sickness among women in the Swedish public sector. Productivity was enhanced at the expense of intensified stress and heavier workloads (Lidwall 2010).

What is more, the encouraging Swedish GDP development from the mid 1990s until the financial crisis was not explained by the initial tightening of fiscal policies or the radical fiscal rules (or the budget reforms at the central government level), but primarily by an international upswing and a favourable exchange-rate development 
and industrial composition. The industrial structure explains, inter alia, why Sweden benefited from strong positive productivity shocks. Besides, automatic stabilizers and re-evaluation of debts and assets, not fiscal restraint, was the main reason for the significant decline in Swedish public debt from the mid 1990s. And the exogeneity of the fiscal rules (and new budget processes) may be called into question in light of the traumatic economic and financial crisis in the country in the early 1990s and the priorities of the new consensus in macroeconomics.

The story of a successful new fiscal (and monetary) regime in Sweden is also challenged by the fact that the country has not been successful in all respects since the mid 1990s. The labour force participation rate (16-64 years old) has not yet returned to the high levels prior to the deep recession in the early 1990s, although Sweden still belongs to the group of OECD countries with the highest rates (OECD Employment Outlook 2005, table B; 2014, table C). And inequality in incomes after taxes, transfers and social insurances has increased dramatically in Sweden since the mid 1980s. As late as 2004, distribution of household disposable income was still more equal in Sweden than in all other OECD countries (Gini coefficients). But in 2011, Sweden was outside the group of OECD countries with the smallest net income gaps although the country still (2012) had the most equal wage distribution (OECD 2011; 2014; OECD Employment Outlook 2014, table N).

Furthermore, since the early 1990s, Sweden is no longer in the group of OECD countries with the lowest rate of unemployment. The strict inflation target of the Riksbank, which is a more basic restriction on fiscal policy than the fiscal rules, and the actual deviations downward from the inflation target (for other reasons than fiscal policy) are pivotal explanations for why Sweden never approached the low rates of unemployment customary before the economic crisis of the early 1990s. But Swedish governments have not used the discrepancy between the inflation target and the actual rate of inflation by pursuing a looser fiscal policy. For example, at the beginning of the global financial crisis, Swedish fiscal policy was restrictive despite a negative rate of inflation. The fact that Sweden has since got off lightly from the international financial and debt crises cannot be related to the country's fiscal policy, but to her independent monetary policy, which primarily made it possible to counteract a housing and stockmarket boom in the mid 2000s, depreciation of the SEK (2008-2009) and avoidance of a bank crisis by luck.

A positive lesson from Sweden is that medium-term rules for the public budget balance are compatible with substantial fiscal stimuli in a recession; we ignore here the tremendous difficulties in defining the medium term in practice. This advantage of the Swedish fiscal rules was obvious in the early 2000s, although the budget deficit for general government never came near the SGP target of 3 per cent, or was really explained by the design of these rules (see the impact of the political business cycle). Another positive lesson from Sweden in the most recent decades is that it is possible to establish a consensus about a non-populist economic policy in a democracy, and to accomplish painful fiscal austerity measures even with minority governments.

A negative lesson from Sweden is that medium-term fiscal rules can also be too rigid in a deep and lengthy international recession, especially if escape clauses are missing. The Swedish example also shows that stipulations of a public budget surplus instead of a budget balance in the medium term may be too strong in this situation. Another negative lesson from Sweden is that independent Central Banks governed by a demanding inflation target and an overambitious executive board, may, in themselves or in conjunction with fiscal rules, lead to priorities in economic policy that conflict with the preferences of the political system. A further negative lesson from Sweden is that the 
introduction of a 'responsible' fiscal policy in the mid 1990s was founded on the uncritical acceptance of new economic thinking, downplaying the obvious conclusion that fiscal austerity has deflationary effects. An analysis of the effects of Swedish fiscal policy cast doubt over the possibility for the European Commission, leading European politicians and international lenders to lean on Swedish experiences when recommending fiscal austerity measures for EMU countries with large public debt.

\section{REFERENCES}

Afonso, A. and C. Rault (2010), 'Long-run behaviour of long-term sovereign bond yields', CESifo Working Paper Series No 3249, Munich: CESifo Group.

Ahrend, R., P. Catte and R. Price (2006), 'Interactions between monetary and fiscal policy: how monetary conditions affect fiscal consolidation', OECD Economics Department Working Paper No 521, Paris: OECD.

Alesina, A. and R. Perotti (1999), 'Budget deficits and budget institutions', in J.M. Poterba and J. von Hagen (eds), Fiscal Institutions and Fiscal Performance, Cambridge, MA: National Bureau of Economic Research, University of Chicago Press.

Alexius, A. and E. Post (2008), 'Exchange rates and asymmetric shocks in small open economies', Empirical Economics, 35(3), 527-541.

Andersson, B., S. Palmqvist and P. Österholm (2012), 'The Riksbank's attainment of its inflation target over a longer period of time', Economic Commentaries No 4, Stockholm: The Riksbank.

Auerbach, A.J. (2012), 'Budget rules and fiscal policy: then lessons from theory and evidence', Paper presented at a conference on Government Debt in Democracies: Causes, Effects, and Limits, Berlin, 30 November-1 December 2012, mimeo.

Badinger, H. (2009), 'Fiscal rules, discretionary fiscal policy and macroeconomic stability: an empirical assessment for OECD countries', Applied Economics, 41(7), 829-847.

Barnes, S., D. Davidsson and L. Rawdanowics (2012), 'Europe's new fiscal rules', OECD Economics Department Working Paper No 972, Paris: OECD.

Barro, R.J. (1990), 'Government spending in a simple model of endogenous growth', Journal of Political Economy, 98(5), S103-S125.

Barro, R.J. and X. Sala-i-Martin (2004), Economic Growth: Second Edition, Cambridge, MA and London: MIT Press.

Bassanini, A. and S. Scarpetta (2001), 'The driving forces of economic growth: panel data evidence for the OECD countries', OECD Economic Studies, 33(II), 9-56.

Beltramello, A., K. de Backer and L. Moussiegt (2012), 'The export performance of countries within global value chains (GVCs)', OECD Science, Technology and Industry Working Papers No 2012/02, Paris: OECD.

Blanchard, O. (1991), 'Current and anticipated deficits, interest rates and economic activity', in G. de Ménil and R.J. Gordon (eds), International Volatility and Economic Growth: The First Ten Years of The International Seminar on Macroeconomics, Cambridge, MA: National Bureau of Economic Research, pp. 361-390.

Braconier, H. and S. Holden (1999), 'The public budget balance: fiscal indicators and cyclical sensitivity in the Nordic countries', NIER Working Paper No 67, Stockholm and Oslo, the National Institute of Economic Research (Konjunkturinstitutet) and Department of Economics, Oslo University.

Brook, A.-M. (2003), 'Present and prospective trends in real long-term interest rates: fiscal policy and other drivers', OECD Economics Department Working Papers No 367, Paris: OECD.

Budina, N., T. Kinda, A. Schaechter and A. Weber (2012), 'Fiscal rules at a glance: country details from a new dataset', IMF Working Paper No 273, Washington, DC: International Monetary Fund.

Carlin, W. and D. Soskice (2006), Macroeconomics: Imperfections, Institutions and Policies, Oxford and New York: Oxford University Press. 
Castro, V. (2007), 'The impact of the European Union fiscal rules on economic growth', The Warwick Economics Research Paper Series No 794, Warwick: Department of Economics, University of Warwick.

CESifo (2012), 'Main fiscal rules in selected OECD countries, 2010', DICE database, Munich: CESifo Group.

Claeys, P. (2008), 'Rules, and their effects on fiscal policy in Sweden', Swedish Economic Policy Review, 15(1), 7-47.

Combes, J.L., X. Debrun, A. Minea and R. Tapsoba (2014), 'Inflation targeting and fiscal rules: do interactions and sequencing matter?' IMF Working Paper No 89, Washington, DC: International Monetary Fund.

Dagens Nyheter (2015), 3 and 16 March, Debatt.

Dahan, M. and M. Strawczynski (2010), 'Fiscal rules and composition bias in OECD countries', Working Paper Series No 3088, Munich: CESifo Group.

Debrun, X., L. Moulin, A. Turrini, J. Ayuso-i-Casals and M.S. Kumar (2008), 'Tied to the mast? National fiscal rules in the European Union', Economic Policy, 23(4), 297-362.

Dixit, A. and L. Lambertini (2000), 'Fiscal discretion destroys monetary commitment', Princeton University and UCLA, mimeo.

Dixit, A. and L. Lambertini (2003), 'Interactions of commitment and discretion in monetary and fiscal policies', American Economic Review, 93(5), 1522-1542.

Dixit, A. and R. Pindyck (1994), Investment Under Uncertainty, Princeton, NJ: Princeton University Press.

Edquist, H. (2009), 'Hur länge förblir IKT avgörande för svensk produktivitetstillväxt?' ['For how long a time will the ICT sector be decisive for Swedish productivity growth?'], Ekonomisk Debatt, 37(1), 31-40.

Edvinsson, R. (2005), Growth Accumulation Crisis: With New Macroeconomic Data for Sweden, 1800-2000, PhD thesis, Stockholm Studies in Economic History 41, Stockholm: Stockholm University.

Erixon, L. (2011), 'Under the influence of traumatic events, new ideas, economic experts and the ICT revolution - the economic policy and macroeconomic performance of Sweden in the 1990s and 2000s', Comparative Social Research, 28(1), 265-329.

Erixon (2013), 'Ekonomisk tillväxt' ['Economic growth'], in M. Persson and E. Skult (eds), Tillämpad makroekonomi [Applied Macroeconomics], Stockholm: Studentlitteratur, pp. 89-102.

Erixon, L. and E. Skult (1996), 'Regeringen jagar hjärnspöken' ['The government chases the bogeyman'], LO-tidningen, 9 February, Stockholm.

European Commission (2006), 'Public finances in EMU 2006', European Economy, No 3, Directorate-General for Economic and Financial Affairs, Brussels, The European Union.

European Commission (2010), 'Public finances in EMU 2010', European Economy, No 4, Directorate-General for Economic and Financial Affairs, Brussels, the European Union.

European Commission (2014), 'Fiscal Rule Index', database (available at: http://ec.europa.eu/ economy_finance/db_indication/fiscal governance/fiscal rules/index en.htm).

Flodén, M. (2012), 'A role model for the conduct of fiscal policy? Experiences from Sweden', CEPR Discussion Paper no 9095, July. (A shorter version is published in Journal of International Money and Finance, 2013, 34, 177-197.)

Fountas, S. and M. Karanasos (2007), 'Inflation, output growth, and nominal and real uncertainty: empirical evidence for the G7', Journal of International Money and Finance, 26(2), 229-250.

Franchino, F. (2014), 'The design of fiscal governance rules of the European Union', Seminar in Politics and Society, 30 January, Turin: Collegio Carlo Alberto.

Franco, D. and F. Zotteri (2010), 'Ensuring fiscal sustainability: which role for fiscal rules? The experience of European countries', The 66th Congress of the International Institute of Public Finance, Uppsala, Sweden.

Friedman, M. (1977), 'Nobel lecture: inflation and unemployment', The Journal of Political Economy, 85(3), 451-472. 
Gemmell, N., R. Kneller and I. Sanz (2007), 'Fiscal policy impacts on growth in the OECD: are they long-run?', University of Nottingham, mimeo.

Gemmell, N., R. Kneller and I. Sanz (2011), 'The timing and persistence of fiscal policy impacts on growth: evidence from OECD countries', The Economic Journal, 121(550), F33-F58.

Giavazzi, F. and M. Pagano (1990), 'Can severe fiscal contractions be expansionary? Tales of two small European countries', NBER Macroeconomics Annual, 5(11), 75-122.

Girouard, N. and C. André (2005), 'Measuring cyclically-adjusted budget balances for OECD countries', OECD Economics Department Working Papers No 434, Paris: OECD.

Government Offices of Sweden (2014), Sweden's Convergence Programme 2014, Stockholm.

Grier, K. and M. Perry (2000), 'The effects of real and nominal uncertainty on inflation and output growth: some GARCH-M evidence', Journal of Applied Econometrics, 15(1), 45-58.

Grier, K., O. Henry, N. Olekalns and K. Shields (2004), 'The asymmetric effects of uncertainty on inflation and output growth', Journal of Applied Econometrics, 19(5), 551-565.

Henriksson, J. (2012), Using Frontloading as a Signal in Budget Consolidation, PhL thesis, The Institute for International Economics, Stockholm University, Stockholm.

International Monetary Fund (2012), 'Staff country reports - Finland', IMF Country Report No 254, Washington, DC: International Monetary Fund.

Kalecki, M. (1954 [1965]), Theory of Economic Dynamics, New York and London: MR Modern Reader.

Kalecki, M. (1968), 'Trend and business cycles reconsidered', The Economic Journal, 78(310), 263-276.

Kónya, L. (2004), 'Unit-root, cointegration and Granger causality test results for export and growth in the OECD countries', International Journal of Applied Econometrics and Quantitative Studies, 1(2), 67-94.

Kopits, G. and S. Symanski (1998), 'Fiscal rules', IMF Occasional Paper 162, Washington, DC: International Monetary Fund.

Laopodis, N. (2002), 'Volatility linkages among interest rates: implications for global monetary policy', International Journal of Finance and Economics, 7(3), 215-233.

Lidwall, U. (2010), Long-Term Sickness Absence: Aspects of Society, Work, and Family, $\mathrm{PhD}$ thesis, Sektionen för Försäkringsmedicin, Karolinska Institutet, Stockholm,.

Ljungberg Ording, A. (2014), The Effects of Uncertainty on Inflation and Output Growth: Evidence from Sweden, Master thesis, Department of Economics, Stockholm University, mimeo.

Lönnroth, J. (2004), 'Den enfaldige politikern' ['The simple-minded politician'], Ekonomisk Debatt, 32(7), 6-20.

Lundborg, P. and H. Sacklén (2006), 'Low-inflation targeting and long-run unemployment', Scandinavian Journal of Economics, 108(3), 397-418.

Lundgren, S. (ed.) (2007), 'Tillväxt i otakt' ['Unbalanced growth'], Konjunkturrådets rapport 2007 [Report from SNS Economic Policy Council 2007], SNS Förlag, Stockholm.

Matthiessen, L. (1971), 'Finanspolitiken som stabiliseringspolitiskt instrument' ['Fiscal policy as an instrument in stabilization policy'], in Svensk finanspolitik $i$ teori och praktik, Stockholm, Aldus/Bonniers, pp. 164-226.

Miyazaki, Tomomi (2011), 'Fiscal reform and fiscal sustainability: evidence from selected OECD countries', Working Paper No 4, Faculty of Economics, Toyo University.

Muller, P. and R.W.R. Price (1984), 'Structural budget deficits and fiscal stance', OECD Economics and Statistics Department Working Papers No 15, Paris: OECD.

National Board of Trade (2013), 'Sveriges utrikeshandel med varor och tjänster samt direktinvesteringar', National Board of Trade (Kommerskollegium) HA 22 SM 1301, March, Stockholm: National Board of Trade.

National Board of Trade (2014), 'Sveriges utrikeshandel med varor och tjänster samt direktinvesteringar', National Board of Trade (Kommerskollegium) HA 22 SM 1401, March, Stockholm: National Board of Trade.

OECD (2002), 'Fiscal sustainability: the contribution of fiscal rules', ch. IV in OECD Economic Outlook 2002, Paris: OECD.

OECD (2002 and 2005), National Accounts of OECD Countries, OECD: Paris. 
OECD (2009), Economic Outlook, Interim report, Paris: OECD.

OECD (2011), 'Growing inequality in OECD countries: what drives it and how can policy tackle it?' OECD Forum on Tackling Inequality, Paris: OECD.

OECD (2014), 'Income inequality update. Rising inequality: youth and poor fall further behind', OECD Directorate for Employment Labour and Social Affairs, Statistics Directorate, Paris: OECD.

OECD Economic Outlook, periodical (various dates), two nos per year, Paris: OECD.

OECD Employment Outlook, periodical (various dates), one no per year, Paris: OECD.

Reicher, C.P. (2013), 'A set of estimated fiscal rules for a cross section of countries: stabilization and consolidation through which instruments?' Kiel Working Papers No 1850, Kiel: Kiel Institute for the World Economy.

Riksbank, The (1994), 'Inflation och inflationsförväntningar I Sverige' ['Inflation and inflation expectations in Sweden'], Ekonomiska Avdelningen [the Economic Department], October, Stockholm: the Riksbank.

Riksbank, The (1995), 'Inflation och inflationsförväntningar I Sverige' ['Inflation and inflation expectations in Sweden'], Ekonomiska Avdelningen [the Economic Department], February, Stockholm: the Riksbank.

Riksbank, The (1996a), 'Inflationsrapport 1' ['Inflation Report No 1'], March, 2006, Stockholm: the Riksbank.

Riksbank, The (1996b), 'Inflationsrapport 2' ['Inflation Report No 2'], June, 2006, Stockholm: the Riksbank.

Riksbank, The (2011), 'Lämplig kapitalnivå i svenska storbanker - en samhällsekonomisk analys' ['An optimal capital requirement for the Swedish big banks - a cost-benefit analysis'], Stockholm: the Riksbank.

Rother, P.C. (2004), 'Fiscal policy and inflation volatility', ECB Working Paper Series No 317, Frankfurt am Main: European Central Bank.

Schaechter, A., T. Kinda and A. Weber (2012), 'Fiscal rules in response to the crisis - toward the “next-generation" rules. A new dataset', IMF Working Paper No 187 2013, Washington, DC: International Monetary Fund.

Söderström, U. and A. Vredin (2013), 'Inflationen, arbetslösheten och penningpolitiken' ['Inflation, unemployment and monetary policy'], Economic Commentaries No 1, Stockholm: the Riksbank.

SOU (1993:16), 'Nya villkor för ekonomi och politik. Ekonomikommissionens förslag' ['New conditions in the economy and for policy making - the Lindbeck Commission'], Stockholm: Allmänna Förlaget.

Svensson, L.E.O. (2010), 'Förväntningar om och utvärdering av penningpolitiken: vilken roll spelar öppenhet och kommunikation?' ['Expectations and evaluation of monetary policy: what is the role of transparency and communication?'], Penning- och Valutapolitik, 1(1), 44-80.

Svensson, L.E.O. (2015), 'The possible unemployment cost of average inflation below a credible target', American Economic Journal: Macroeconomics, 7(1), 258-296.

Swedish Economic Association (1995), 'Nationalekonomiska föreningens förhandlingar, Finansplanen och den ekonomiska politiken' ['Discussion of the Budget Bill'], Meeting, 18 January, Ekonomisk Debatt, 23(1), 79-104.

Swedish Economic Association (1997), 'Nationalekonomiska föreningens förhandlingar, Finansplanen och den ekonomiska politiken' ['Discussion of the Budget Bill'], Meeting, 24 September 1996, Ekonomisk Debatt, 25(1), 46-76.

Swedish Government (1996), 'En politik för arbete, trygghet och utveckling', Government Proposition 1995/96:25, Stockholm: Fritzes.

Swedish Ministry of Finance (1994), Swedish Budget Bill 1994/1995, Proposition 1994/95:100, Stockholm: Swedish Ministry of Finance.

Swedish Ministry of Finance (1995a), Revised Swedish Budget Bill 1994/1995, Proposition 1994/95: 150, Stockholm: Swedish Ministry of Finance.

Swedish Ministry of Finance (1995b), 'Konvergensprogram för Sverige' ['Convergence Programme for Sweden'], June, Stockholm: Swedish Ministry of Finance. 
Swedish Ministry of Finance (1996), Swedish Budget Bill 1995/1996, Proposition 1995/96: 150, Stockholm: Swedish Ministry of Finance.

Swedish Ministry of Finance (1997), Revised Budget Bill 1998, Proposition 1997/98:1, Stockholm: Swedish Ministry of Finance.

Swedish Ministry of Finance (1998), Revised Swedish Budget Bill 1999, Proposition 1998/99:1, Stockholm: Swedish Ministry of Finance.

Swedish Ministry of Finance (1999), 'Updated Swedish Convergence Programme', Stockholm: Swedish Ministry of Finance.

Swedish Ministry of Finance (2000a), 'Finans- och penningpolitiskt bokslut för 1990-talet', appendix 5 to the Budget Bill for Sweden 2000/01, Stockholm: Fritzes.

Swedish Ministry of Finance (2000b), Swedish Budget Bill 2000, Proposition 1999/2000:100, Stockholm: Swedish Ministry of Finance.

Swedish Ministry of Finance (2007), Swedish Budget Bill 2008, Proposition 2007/08:1, Stockholm: Swedish Ministry of Finance.

Swedish Ministry of Finance (2009), Swedish Budget Bill 2009, Proposition 2008/09:100, Stockholm: Swedish Ministry of Finance.

Swedish Ministry of Finance (2014a), Spring Fiscal Policy Bill for 2014, Stockholm: Swedish Ministry of Finance.

Swedish Ministry of Finance (2014b), Swedish Budget Bill for 2014, Proposition 2014/15:1, Stockholm: Swedish Ministry of Finance.

Upper, C. and A. Worms (2003), 'Real long-term interest rates and monetary policy: a crosscountry perspective', in Bank for International Settlements (ed.), Monetary Policy in a Changing Environment, BIS Papers vol. 19, pp. 234-257. 